\title{
Dance and Parkinson's: A review and exploration of the role of cognitive representations of action
}

DOI:

10.1016/j.neubiorev.2019.12.023

\section{Document Version}

Accepted author manuscript

Link to publication record in Manchester Research Explorer

\section{Citation for published version (APA):}

Bek, J., Arakaki, A., Lawrence, A., Sullivan, M., Ganapathy, G., \& Poliakoff, E. (2020). Dance and Parkinson's: A review and exploration of the role of cognitive representations of action. Neuroscience and Biobehavioral Reviews, 109, 16-28. https://doi.org/10.1016/j.neubiorev.2019.12.023

\section{Published in:}

Neuroscience and Biobehavioral Reviews

\section{Citing this paper}

Please note that where the full-text provided on Manchester Research Explorer is the Author Accepted Manuscript or Proof version this may differ from the final Published version. If citing, it is advised that you check and use the publisher's definitive version.

\section{General rights}

Copyright and moral rights for the publications made accessible in the Research Explorer are retained by the authors and/or other copyright owners and it is a condition of accessing publications that users recognise and abide by the legal requirements associated with these rights.

\section{Takedown policy}

If you believe that this document breaches copyright please refer to the University of Manchester's Takedown Procedures [http://man.ac.uk/04Y6Bo] or contact uml.scholarlycommunications@manchester.ac.uk providing relevant details, so we can investigate your claim.

\section{OPEN ACCESS}




\title{
Manuscript Details
}

\section{Manuscript number}

Title
NEUBIOREV_2019_393_R2

Dance and Parkinson's: A review and exploration of the role of cognitive representations of action

Review Article

\section{Article type}

\begin{abstract}
Parkinson's disease (PD) is a neurodegenerative disease causing both sensorimotor and non-motor impairments, and there is a clear need for non-medical approaches to improve quality of life. Dance is an increasingly popular activity among people with PD, which demonstrates potential therapeutic benefits. However, findings to date have been inconsistent, and little is known about the mechanisms underlying benefits of dance in PD. In this review, we provide an overview of research into dance for people with PD. The majority of evidence is in the sensorimotor domain, but cognitive, psychological and social effects have also been reported. We consider the role of cognitive representations of action within dance through observation, imitation and imagery, which may contribute to both sensorimotor and nonmotor outcomes for people with PD. Moreover, we discuss how these processes may be enhanced through dance to provide further benefits in everyday life. Finally, we propose avenues for future research to increase understanding of action representation in dance for PD, which has the potential to inform practice and maximize benefits.
\end{abstract}

Keywords

Corresponding Author

Corresponding Author's Institution

Order of Authors

Suggested reviewers
Parkinson's disease; quality of life; symptoms; dance; intervention; action representation; motor imagery; imitation; action observation; music; simulation; embodiment.

Judith Bek

University of Manchester

Judith Bek, Aline Arakaki, Adam Lawrence, Matthew Sullivan, Gayathri Ganapathy, Ellen Poliakoff

Daniel Eaves, Peter Lovatt, Bettina Blasing, Will Young

\section{Submission Files Included in this PDF}

\section{File Name [File Type]}

Dance and action representation in PD Bek et al resubmission 2 Cover Letter.docx [Cover Letter]

Dance and action representation in PD Bek et al resubmission_2 Response.docx [Response to Reviewers]

Dance and action representation in PD Bek et al Highlights.docx [Highlights]

Dance and action representation in PD Bek et al Abstract.docx [Abstract]

Dance and action representation in PD Bek et al Title Page.docx [Title Page (with Author Details)]

Dance and action representation in PD Bek et al resubmission_2 Manuscript.docx [Manuscript File]

Dance and action representation in PD Bek et al resubmission_2 Table 1.docx [Table]

Dance and action representation in PD Bek et al resubmission Supplement.pdf [Table]

To view all the submission files, including those not included in the PDF, click on the manuscript title on your EVISE Homepage, then click 'Download zip file'.

\section{Research Data Related to this Submission}

There are no linked research data sets for this submission. The following reason is given:

No data was used for the research described in the article 
Dear Dr Cirulli,

Thank you for the opportunity to further revise our manuscript, "Dance and Parkinson's: A review and exploration of the role of cognitive representations of action", following the reviewers' latest comments. We have responded to these comments in the attached document, explaining the changes we have made.

The reviewers' suggestions have been very helpful in enabling us to further enhance the manuscript and provide additional clarification and consistency throughout the paper. We are grateful to the reviewers for taking the time and care to give such useful and comprehensive feedback.

Yours sincerely,

Judith Bek

Corresponding author:

Judith Bek, Zochonis Building, University of Manchester, Oxford Road, Manchester M13 9PL, UK.

Telephone: +441613060430

Email: judith.bek@manchester.ac.uk

Co-authors:

Aline I Arakaki aline.arakaki@manchester.ac.uk

Adam Lawrence a.c.lawrence@ljmu.ac.uk

Matthew Sullivan m.sullivan@mmu.ac.uk

Gayathri Ganapathy gganapathy@equintl.com

Ellen Poliakoff ellen.poliakoff@manchester.ac.uk 


\section{Reviewer 1}

The revised manuscript has improved in particular through the provision of relevant supporting evidences. While it does have the potential for a strong and coherent theoretical review paper; there are a number of shortcomings. I highly recommend the authors to address these carefully by considering the manuscript as a whole in their revision.

Overall, the changes were done in a piecemeal fashion, which reduced the coherence of the manuscript.

- We thank the reviewer for these suggestions. We have carefully considered the flow and coherence of the manuscript, and have made changes to the sections highlighted below as well as in other places (for example, restructuring Section 4).

To provide some examples: On page 8 , the authors refer to a single case study as supporting evidence for functional brain changes through dance training in PD. Yet on page 14, the authors appropriately refer to the large controlled trial study by Myers et al. 2018 that did not identify advantages for neuronal changes in response to dance compared to exercise. The two references need to consideration within the same realm to provide an objective picture of existing evidence.

- The Myers et al. (2018) study is now introduced within the discussion of neuroimaging evidence on p8 and we have rephrased the citation on $\mathrm{p} 13$ within the discussion of effects of dance on motor imagery:

[P8] "In a larger-scale trial using fMRI to investigate effects of Tango, treadmill training and stretching (Myers et al., 2018), no change was found in activity of the somatomotor network after 12 weeks; however, separate results were not reported for each intervention. Further evidence is clearly needed to elucidate neuroplastic changes and mechanisms of neuroprotection in relation to dance in people with PD."

[P13] "Another study (Myers et al., 2018) found no change in neural activity during motor imagery of gait but, as noted above, the results were combined for participants receiving three different interventions (Tango, treadmill training, and stretching), which may have masked any dance-specific effects."

Similarly, in a number of paragraphs, the authors jump between topics, thus lacking coherence. For example, on page 21, the authors discuss live-vs-digital representation before discussing eye movement measures, to continue elaborating virtual or augmented reality studies.

- We have restructured Section 4.3 (now 4.2) to improve the flow between paragraphs.

Also, on page 19, it is not quite clear why dance styles and individual differences are discussed in the same section since the first and second paragraph are unrelated.

- Subsections 4.1. and 4.2. have been combined under the broader subheading "4.1. Investigating action representation in dance for Parkinson's", which encompasses proposed research into effects of action representation within dance across domains, and considers the influence of different dance styles and individual differences in relation to this.

Table 1 is extremely useful for further research and theoretical considerations; and I appreciate the authors work on this. However, it does in fact contradict the authors' focus on Tango as a dance intervention style. For example, on page 9, one reads: "To date, few published studies have investigated styles other than tango". Looking at the number of studies in table 1, while there are indeed more studies cited that employed tango as the dance intervention style overall, this is not the case for certain measures. Notably, the number of studies that found evidence for improvement through Tango practice across the measures is not significant. The text does 
require further clarification on this point. Further, in my view, providing actual numbers of studies would be a useful addition and clarification of the relevance of Tango as a dance style in consideration of its evidence for enhancement in PDs.

- Our aim is not to propose that Tango confers greater benefits than other dance styles, but to emphasise the need for further research across a range of different dance forms, since Tango has been investigated more than other styles. We have edited the manuscript to ensure that our point comes across as clearly as possible:

[P9] "Of the studies included in this review, the majority focused on Tango $(n=18)$, with others investigating effects of modern dance $(n=4)$, Irish set dance $(n=3)$, ballet $(n=1)$, Waltz/Foxtrot $(n=1)$, DMT $(n=1)$, or mixed styles including Dance for PD $(n=8) . "$

[P21] "Another consideration for future research is that different dance styles may vary in the extent to which imagery and observation are used, or the explicitness of action representation processes. For example, improvisational dance may rely less on action observation but may have a stronger emphasis on imagery, while partnered dance may involve a greater influence of touch rather than observation during learning. These differences and their relationships to physical, social and emotional outcomes of dance could therefore be investigated."

Other points:

- $\quad$ Page 8 first sentence "The majority...", is not evident from the preceding text

- We have corrected this statement to read "The majority of quantitative evidence to date showing potential benefits of dance for PD is in the sensorimotor domain, focusing on aspects of balance and gait, general severity of motor impairment, and functional mobility"

- $\quad$ Page 8 last sentence in first paragraph "Additionally, ..." is repetitive

- We were not able to identify where the repetition is in this sentence; however, if the reviewer is able to clarify this point we would be happy to address it.

- $\quad$ Page $83^{\text {rd }}$ paragraph is not clear in relation to the manuscript as a whole

- We acknowledge that this point is peripheral to the key aims of the manuscript, and the need for further research into long-term outcomes is also noted on p22 ("The relationship between action representation, music and movement in people with PD should also be explored, as well as longer-term outcomes in terms of neural changes in sensorimotor areas associated with action representation and transfer of skills to everyday tasks."); we have therefore removed this paragraph.

- $\quad 2^{\text {nd }}$ paragraph page 15 is too vague.

- We have added further detail to this paragraph to clarify the effects reported in the cited research:

[P14] "In healthy individuals, physiological responses (skin conductance) and subjective ratings of emotion when observing expressive movements have been found to be influenced by experience of dancing (Christensen et al., 2016), such that trained dancers were more sensitive than non-dancers to differences between movements expressing happiness and sadness. Moreover, dancers showed a closer correspondence between physiological measures and affective ratings. These findings indicate that dance 
training can enhance embodiment of observed actions, and has the potential to improve emotional and social processing in people with PD."

- It would be of interest to understand "how" the authors understand that group or partner work is proposed to enhance inhibitory control.

- This point has been elaborated upon to explain the rationale behind our suggestion, and we have inserted relevant references:

[P15] "However, inhibitory processes can be improved with practice (e.g., Spierer et al., 2013). Group or partner work in dance may therefore contribute to not only increased social imitation (e.g., Heyes, 2013), but also improved inhibitory control and coordinative action (e.g., via turn-taking, leading and following), resulting in enhanced interaction and communication."

- Page 18: "Music could also provide a cue outside of classes" The authors could expand on this with empirical evidence

- We have added a reference to support this point:

[P19] "Music could also provide a cue outside of classes, evoking representations of associated actions or qualities of motion (e.g., Eitan and Granot, 2006) to facilitate movement."

- $\quad$ 4.1. is interesting, but the paragraph does not follow up on the notions.

- As noted above, we have now restructured Section 4, incorporating proposed research into both motor and non-motor effects of dance in relation to action representation in Section 4.1.

- There are a number of repetitions in the manuscript that should be corrected, for example, page 19: "To date, the majority of studies of dance in relation to PD have involved forms of Tango." By that point, this statement has appeared a number of times.

- Although we felt it appropriate to re-emphasise certain points in different sections of the manuscript, we appreciate that this may appear repetitive to the reader, and have removed or rephrased repeated statements accordingly.

- $\quad$ Page 21: "Nonetheless, as discussed above, video-based..." The studies provided in the section above did not support that evidence (as they were video-supported; not video-based training sessions).

- We realise that this statement may not have been entirely clear, as it referred to the prior discussion of action observation therapies in PD (Section 3.1), rather than the studies immediately preceding this paragraph. This has been rewritten for clarification and we have also incorporated the point about social interaction in participatory dance from later in the section:

[P20-21] "It should be noted that live observation - both for dance and other actions - has been found to increase sensorimotor activity compared with digital observation (Jola and Grosbras, 2013). Additionally, the social element of dance is important to people with PD (Houston \& McGill, 2013; Kunkel et al., 2018), and the group setting likely promotes greater use of imitation, coordination, and communicative and expressive action. Nonetheless, as discussed in Section 3.1, video-based action observation therapies have shown positive effects in people with PD."

- $\quad$ Page 20: The definition of kinaesthetic empathy is misleading. Reason and Reynolds described it as the ability to experience empathy merely by observing movements of another human being. To my knowledge, it has not 
been investigated if they spectators had the same 'feeling' (spectators have muscle-specific motor resonance; which does not imply the same 'feeling')

- We have rephrased this point:

[P20] "The term "kinaesthetic empathy" has been used in relation to dance and neuroaesthetics (Jola et al., 2012b; Reason and Reynolds, 2010), to describe a process of embodiment in which audiences may internally simulate the dancers' movements when watching a performance."

- " "participation" in the following sentence is wrong (or misleading in this context as 'dance participation in the studies') and should be corrected with 'expertise' or 'training'

- This has now been rephrased:

[P20] "Neuroimaging evidence has indicated the involvement of sensorimotor processes when watching dance (Calvo-Merino et al., 2008, 2005; Cross et al., 2009, 2006); moreover, experience in observing dance even without physical training can increase corticomotor responses to familiar dance movements (Jola et al., 2012a)."

- $\quad$ Page 22: do the authors mean iii: dance can enhance motor imagery and embodiment in PD?

- The aim of this paragraph is to explain that we are bringing together evidence from different literatures (both on PD and non-PD research) and drawing on this to hypothesise roles of action representation in dance for PD. We have rephrased this for clarification:

[P22] "Evidence from various lines of investigation indicates that (i) action observation, imitation and motor imagery can facilitate movement in people with PD; (ii) dance can enhance motor imagery and embodiment in healthy participants; and (iii) action observation and imagery may contribute to physical and emotional effects of dance."

- Overall in-text citations need correction (use of brackets)

- We thank the reviewer for pointing out this formatting issue, which we have corrected throughout the manuscript.

\section{Reviewer 2}

- The authors have replied to all my comments and they did a great job in improving the paper.

- We thank the reviewer for their previous comments, which have contributed to the improvement and clarification of the manuscript. 
Dance and Parkinson's: A review and exploration of the role of cognitive representations of action

\section{Highlights}

- Dance can provide both motor and non-motor benefits in Parkinson's disease (PD)

- Dance utilises internal action representations through observation and imagery

- Music promotes and supports action representation in dance

- Action representation may contribute to positive effects of dance for PD

- Future research should explore mechanisms of action representation in dance for PD 


\begin{abstract}
Parkinson's disease (PD) is a neurodegenerative disease causing both sensorimotor and non-motor impairments, and there is a clear need for non-medical approaches to improve quality of life. Dance is an increasingly popular activity among people with $\mathrm{PD}$, which demonstrates potential therapeutic benefits. However, findings to date have been inconsistent, and little is known about the mechanisms underlying benefits of dance in PD.

In this review, we provide an overview of research into dance for people with PD. The majority of evidence is in the sensorimotor domain, but cognitive, psychological and social effects have also been reported. We consider the role of cognitive representations of action within dance through observation, imitation and imagery, which may contribute to both sensorimotor and non-motor outcomes for people with PD. Moreover, we discuss how these processes may be enhanced through dance to provide further benefits in everyday life. Finally, we propose avenues for future research to increase understanding of action representation in dance for PD, which has the potential to inform practice and maximize benefits.
\end{abstract}


Dance and Parkinson's: A review and exploration of the role of cognitive representations of action Judith Bek ${ }^{1}$, Aline I Arakaki $^{1}$, Adam Lawrence ${ }^{1}$, Matthew Sullivan², Gayathri Ganapathy ${ }^{3}$, Ellen Poliakoff ${ }^{1}$

${ }^{1}$ Division of Neuroscience and Experimental Psychology, School of Biological Sciences, Faculty of Biology Medicine and Health, Manchester Academic Health Science Centre, University of Manchester, Oxford Road, Manchester, M13 9PL, United Kingdom.

${ }^{2}$ School of Science and the Environment, E432 John Dalton Building, Manchester Metropolitan University, Oxford Road, Manchester, M16 5BH, United Kingdom.

${ }^{3}$ Equilibrium International, 6 Stretton Avenue, Manchester, M20 6HE, United Kingdom.

Corresponding author:

Judith Bek, Zochonis Building, University of Manchester, Oxford Road, Manchester M13 9PL, UK.

Telephone: +441613060430

Email: judith.bek@manchester.ac.uk

Co-authors:

Aline I Arakaki aline.arakaki@manchester.ac.uk

Adam Lawrence a.c.lawrence@ljmu.ac.uk

Matthew Sullivan m.sullivan@mmu.ac.uk

Gayathri Ganapathy gganapathy@equintl.com

Ellen Poliakoff ellen.poliakoff@manchester.ac.uk 
Dance and Parkinson's: A review and exploration of the role of cognitive representations of action

\section{Keywords}

Parkinson's disease; quality of life; symptoms; dance; intervention; action representation; motor imagery; imitation; action observation; music; simulation; embodiment.

\section{Introduction}

Parkinson's disease (PD) is a neurodegenerative condition affecting more than 1 in 100 people aged over 60 , in which depletion of dopamine in the substantia nigra alters the functioning of basal ganglia circuitry. This results in multiple sensorimotor impairments, including reduced speed and amplitude of movement, rigidity, tremor and balance and gait disturbances. The internal generation of movement, which relies upon cortical-subcortical networks, is particularly affected (Brown and Marsden, 1988); indeed, it has been proposed that the loss of dopamine in the basal ganglia selectively impairs automatic or habitual movement rather than goal-directed actions (Redgrave et al., 2010).

Additionally, PD involves non-motor features including mood disturbances, cognitive impairments and apathy (Chaudhuri et al., 2006). Although recent genetic and pharmacotherapuetic advancements are promising (see Foltynie and Langston, 2018), no disease-modifying treatment for PD is currently available. While symptoms may be controlled to a degree by medications or neurosurgery, there is a clear need for non-medical approaches that can improve everyday functioning and quality of life (e.g., Bek et al., 2016a; Kleiner-Fisman et al., 2013).

Dance is becoming increasingly popular as a therapeutic activity for people living with PD. Combining physical, rhythmic, cognitive, emotional and social elements, dance is complex and multidimensional, with the potential to impact upon multiple domains of functioning in PD (Dhami 
et al., 2015; Houston and McGill, 2013; Kshtriya et al., 2015). Physical activity promotes dopamine release and may offer neuroprotection (Hou et al., 2017), but levels of activity are reduced among people with PD (Nimwegen et al., 2011), and participation can be affected by loss of motivation, low mood and fatigue (Afshari et al., 2017). However, motivation levels and adherence rates among people with PD participating in dance are high (Sharp and Hewitt, 2014), suggesting that long-term participation may be more feasible for dance than other forms of physical or cognitive activity.

This article briefly reviews the current evidence on benefits of dance for people with PD across sensorimotor and non-motor domains. We then discuss a set of mechanisms, based on the internal representation of action, which may underlie some of these effects. In particular, we consider the roles of observation, imitation and imagery in contributing to sensorimotor and non-motor outcomes of dance. Finally, we suggest future directions for research to increase understanding of these mechanisms, in order to further extend the benefits of dance for people living with PD.

\section{Dance and Parkinson's: the existing evidence}

Several review articles on the topic of dance for people with PD have been published in recent years. These include PD-specific meta-analyses (dos Santos Delabary et al., 2018; Kalyani et al., 2019; Lotzke et al., 2015; Shanahan, 2015a; Sharp and Hewitt, 2014) and systematic reviews (Aguiar et al., 2016; Mandelbaum and Lo, 2014), as well as a review of non-motor outcomes of dance in both PD and healthy ageing (McNeely et al., 2015a) and a broader review on dance and ageing (Kshtriya et al., 2015). The above meta-analyses, which included between 5 and 13 studies, reported evidence of short-term benefits to people with PD in terms of general motor impairment severity, gait, freezing, balance and functional mobility, as well as some cognitive improvements. Limitations in the existing literature were highlighted, such as the scarcity of randomised controlled trials, the fact that many studies were conducted by the same research groups, small sample sizes, poor quality and risk of bias. It was suggested that future research should examine the optimal dosage and long-term 
benefits of dance, the effects on social interaction and quality of life, and the effects of different dance styles, as well as comparisons with other therapeutic activities..

In the following sections we provide an overview of the current evidence, rather than a comprehensive account of the literature, summarising the effects of dance found in sensorimotor and non-motor domains in people with PD. Table 1 outlines findings in relation to quantitative outcome measures; more detailed summaries of study characteristics and outcomes are provided in the supplementary material.

\subsection{Sensorimotor outcomes}

In the sensorimotor domain, the most commonly reported improvements were in severity of motor impairment based on the Unified Parkinson's Disease Rating Scale (UPDRS or MDS-UPDRS; e.g., Goetz et al., 2008), and balance, assessed using a variety of clinical measures.

Participation in Tango has been associated with reduced motor impairment in uncontrolled studies (Hackney and Earhart, 2009a; Rabinovich et al., 2017), and compared with a no-intervention (Duncan and Earhart, 2012; 2014) or education (McKee and Hackney, 2013) control group.

Motor signs have also been reported to be improved with Irish set dancing in an uncontrolled study (Shanahan et al., 2015b) and when compared to an exercise-based intervention (Volpe et al., 2013), as well as in uncontrolled studies of mixed dance styles (Heiberger et al., 2011; Westheimer et al., 2015) and modern dance (Marchant et al., 2010).

Improvements in balance have been reported following participation in Tango, in 4 uncontrolled studies (see Table 1), and when compared with no-intervention control groups (Duncan and Earhart, 2012; 2014), an education control group (McKee and Hackney, 2013), or exercise or physiotherapy based interventions (Hackney et al., 2007a; Hackney et al., 2007b; Rios Romenets, Anang, Fereshtehnejad, Pelletier, and Postuma, 2015). Modern dance has been associated with improved 
balance in uncontrolled studies (Batson, 2010; Batson, Migliarese, Soriano, Burdette, and Laurienti, 2014; Marchant et al., 2010) and compared with an exercise intervention (Hashimoto et al., 2015). One study of Irish set dancing (Volpe et al., 2013) found an advantage of dance for balance measures compared with individual physiotherapy. Uncontrolled studies of ballet (Houston and McGill, 2013) and "Dance for PD" - an approach specifically developed for people with PD - (Bearss et al., 2017) have also reported improvements in balance.

Findings in relation to aspects of walking and gait (e.g., velocity) and functional mobility have been less consistently found. Improvements in gait were noted for Tango in 4 uncontrolled studies (see Table 1) and when compared with a no-intervention group (Duncan and Earhart, 2012). Functional mobility was found to improve in participants taking Tango classes compared with a no-intervention control group (Duncan and Earhart, 2014), and compared to self-directed exercise (Rios Romenets et al., 2015), traditional rehabilitation (De Natale et al., 2017) or treadmill and stretching programmes (Rawson et al., 2019). Gait was also reported to improve following a mixed-style dance programme compared with a social support control group (Ventura et al., 2016). Irish set dancing was associated with a reduction in freezing of gait and increased functional mobility compared to individual physiotherapy (Volpe et al., 2013), and gait speed was noted to improve in a cross-over control group study of dance/movement therapy (DMT) (Westbrook and McKibben, 1989). Uncontrolled studies have found increased functional mobility following Dance for PD (Bearss et al., 2017), improved self-reported mobility with a mixed dance programme (Heiberger et al., 2011), and improved gait with modern dance (Marchant et al., 2010).

A small number of studies have examined other sensorimotor outcomes. Tango has been associated with improvements in activities of daily living (Duncan and Earhart, 2014) and dexterity (Duncan and Earhart, 2012) compared with a no-intervention control group. An uncontrolled study of "Zumba Gold" for PD using wearable accelerometers during classes found an increase in activity levels over 6 weeks (Delextrat et al., 2016), although this could reflect differences in movement complexity or speed as teaching progressed. Studies using qualitative approaches (e.g., observations, diaries or 
interviews) have also reported sensorimotor outcomes such as improvements in movement quality, body awareness and rigidity in participants taking ballet (Houston and McGill, 2013) and Dance for PD (Westheimer et al., 2015).

Few studies have compared the effects of different dance styles. Hackney and Earhart (2009b) found similar improvements in balance and gait with Tango or American ballroom (Waltz/Foxtrot) classes compared with a no-intervention control group. Comparing outcomes of Tango and Dance for PD, McNeely et al. (2015b) found similar improvements in both groups on repeated sit-to-stand, balance and walking endurance after 12 weeks, although the Tango group showed greater gains for motor signs and functional mobility. The authors note that the movements practiced in Tango overlap more with those assessed by the outcome measures, highlighting the importance of selecting appropriate assessment tools. However, these findings must be interpreted with caution as the Dance for PD programme was compared with an existing Tango programme within another ongoing study.

[Table 1: Outcomes of dance in people with PD]

\subsection{Non-motor outcomes}

Non-motor effects of dance have been investigated in people with PD using approaches such as questionnaires, neuropsychological assessments and qualitative methods. Despite the obvious cognitive demands of dance, only a small number of studies have examined outcomes in this domain for people with PD. Mixed effects on tests of spatial cognition were found following Tango classes when compared with a health education control group (McKee and Hackney, 2013) and on executive function when compared to traditional rehabilitation (De Natale et al., 2017). Using a brief measure of general cognitive function, one study found a trend towards improvement in a Tango group compared with a self-directed exercise group (Rios Romenets et al., 2015), while McKee and 
Hackney (2013) found improvements in both Tango and education groups. Comparing participants of a mixed-style dance programme to a social support group, Ventura et al. (2016) found improvements in verbal working memory and attentional switching but not on measures of executive function, while improved executive function was found following a modern dance intervention compared with exercise or no intervention (Hashimoto et al., 2015).

Dance has also been found to improve mood and affect in PD, although again findings are inconsistent. In uncontrolled studies, a reduction in depression scores was found following participation in Tango (Blandy et al., 2015), and an overall improvement in mood, as well as a specific reduction in anger, was found in people with PD taking part in a mixed dance programme (Lewis et al., 2016). Lower depression scores were found in Dance for PD participants compared with a social support group (Ventura et al., 2016), and for DMT compared with exercise in a cross-over study (Westbrook and McKibben, 1989). Reductions in apathy and depression were also reported for modern dance compared with exercise and no-intervention control groups (Hashimoto et al., 2015). However, other studies did not find improvements in mood and apathy following participation in various dance styles (see Table 1).

Few studies have examined the effects of dance on other non-motor symptoms of PD such as sleep disturbances, pain and fatigue. One study reported improvement in the UPDRS non-motor examination after two years of Tango classes compared with a no-intervention control group (Duncan and Earhart, 2014), and a trend towards a reduction in fatigue was found with Tango compared to self-directed exercise (Rios Romenets et al., 2015).

Self-reported quality of life, encompassing well-being across domains including mood, cognition, mobility and daily activities, has been assessed in several studies of dance for PD. Increased quality of life was found following participation in Tango compared to Tai Chi and a no-intervention control group (Hackney and Earhart, 2009c), as well as in uncontrolled studies of mixed dance styles (Bearss et al., 2017; Bognar et al., 2017; Heiberger et al., 2011; Westheimer, 2008) and Irish set dancing 
(Shanahan et al., 2015b). However, others found no improvement in quality of life with Tango in an uncontrolled study (Blandy et al., 2015) or when compared to an educational control group (McKee \& Hackney, 2013). Self-reported social participation was enhanced in participants of a Tango programme compared with a no-intervention control group, including participation in new activities (Foster et al., 2013). Two further studies without control groups also reported increased social participation in people with PD following Tango (Zafar et al., 2017) or dance for Parkinson's (Bognar et al., 2017) programmes. Additionally, qualitative studies of various dance styles have highlighted further psychosocial outcomes such as increased confidence and motivation (Bognar et al., 2017; Houston and McGill, 2013; Rocha et al., 2017; Westheimer, 2008; Westheimer et al., 2015).

As in the sensorimotor domain, few studies have compared non-motor outcomes between different dance styles. Hackney and Earhart (2009c) reported improved quality of life with Tango but not American ballroom dance, while McNeely et al. (2015b) found no improvement with either Tango or Dance for PD.

When considering non-motor outcomes, it is important to note that participants value the social environment of dance classes (e.g., Houston and McGill, 2013; Kunkel et al., 2018), and partnered dance has been associated with greater enjoyment and motivation to continue compared with nonpartnered dance (Hackney and Earhart, 2010), indicating the importance of social contact in improving well-being. Loss of confidence, apathy and social isolation are likely to impact significantly on quality of life in people with PD (Karlsen et al., 2000); the above findings suggest that dance may address these issues, also leading to engagement in other social activities that could further improve quality of life.

\subsection{Summary of findings}

The majority of quantitative evidence to date showing potential benefits of dance for PD is in the sensorimotor domain, focusing on aspects of balance and gait, general severity of motor impairment, 
and functional mobility. However, improvements have not consistently been found, and many studies are limited by small sample sizes or the absence of control groups, as noted in previous reviews. Additionally, few studies have examined other sensorimotor outcomes, such as fine motor tasks relating to dexterity and activities of daily living.

Some improvements in non-motor domains such as cognition, mood and quality of life have been reported, although other than the most widely-used measure (Parkinson's Disease Questionnaire; PDQ-39; Peto et al., 1995), there is little overlap between studies to allow comparisons to be made. Despite the involvement of emotional and social cognitive processes in dance, these have not been tested quantitatively. Nonetheless, given the importance of non-motor outcomes for the well-being of people with PD, it is important to try to elucidate and understand these effects.

Neurophysiological effects of dance are also poorly understood, having been investigated in only a few studies. A single-case fMRI study found increased functional connectivity between the basal ganglia and premotor cortex following 5 days of intensive modern dance training (Batson et al., 2014), and EEG studies involving small numbers of participants found evidence of changes in muscle synergy during walking and balance tests after 3 weeks of Tango classes (Allen et al., 2017; McKay et al., 2016). In a larger-scale trial using fMRI to investigate effects of Tango, treadmill training and stretching (Myers et al., 2018), no change was found in activity of the somatomotor network after 12 weeks; however, separate results were not reported for each intervention. Further evidence is clearly needed to elucidate neuroplastic changes and mechanisms of neuroprotection in relation to dance in people with PD.

The heterogeneity among previous studies in terms of participant characteristics, intervention duration and intensity, trial design and outcome measures, makes it difficult to identify consistent effects across the literature. In the studies summarized in this review (see supplementary material), interventions have varied in intensity from 45 to 450 minutes per week, with investigations ranging from a single session up to 5 years. Ten studies compared dance with an alternative intervention 
(e.g., exercise programme), 9 compared dance with an inactive control group, and 17 did not include any control or comparison group, while three studies compared different dance styles. Sample sizes ranged from 5 to 26 per group, including participants at various levels of disease progression, from asymptomatic to severe. There were also gender imbalances within and between groups, as well as across studies. Participants were tested on their usual medications in some studies while medication was withheld in others, and several studies did not report medication status. Quantitative and qualitative outcome measures have been used, as well as mixed approaches. Additionally, differences between dance styles mean that some will be more closely aligned with commonly-used clinical assessment tools, whereas others may produce effects best captured by alternative measures. Of the studies included in this review, the majority focused on Tango ( $n=18$ ), with others investigating effects of modern dance $(n=4)$, Irish set dance $(n=3)$, ballet $(n=1)$, Waltz/Foxtrot $(n=$ 1), DMT ( $n=1)$, or mixed styles including Dance for PD $(n=8)$.

In order to advance knowledge of how the benefits of dance for people with PD are achieved, future research should explore the underlying mechanisms of its effects. A better understanding of elements and processes in dance that are particularly effective could inform evidence-based approaches to optimize the benefits of dance across domains and provide a framework for selecting suitable outcome measures for future studies.

Given the complexity of dance as a physical, emotional, cognitive and social activity (Dhami et al., 2015), its efficacy cannot easily be distilled down to a small number of components. Nonetheless, in the following section we discuss one candidate set of processes, based on internal representations of action, which may contribute broadly to both motor and non-motor effects of dance in PD, and could be targeted within dance programmes to further enhance outcomes. 


\section{Dance, action representation and Parkinson's}

Observation of others' movement primes action by engaging a network of brain areas, located primarily in fronto-parietal sensorimotor regions, which overlap with those involved in motor execution (Caspers et al., 2010; Rizzolatti and Sinigaglia, 2010). Movement may be imitated either deliberately - by watching and copying actions - or more spontaneously, such as by inadvertently moving in a similar manner to those around us. Observation and imitation can thus facilitate movement and learning through shared motor representations (Buccino et al., 2004; Lagravinese et al., 2017; Stefan et al., 2008). In dance, these processes of action representation occur naturally: students learn by watching and replicating the instructor's movements, and group or partner work often involves imitating or "mirroring" other dancers.

Motor imagery - sometimes referred to as "mental practice" - shares neural substrates with both observation and execution of actions (Hardwick et al., 2018), and includes visual (imagining what a movement looks like) as well as kinaesthetic (imagining what a movement feels like) components (e.g., Guillot et al., 2009). Widely utilized in sports training and rehabilitation (Schuster et al., 2011), motor imagery is used by dancers to aid learning and enhance movement quality (Blasing et al., 2012; Nordin and Cumming, 2008). Dance experience has been associated with qualitative differences in imagery, including a greater reliance on kinaesthetic representations (Golomer et al., 2008; Jola et al., 2011; Nordin and Cumming, 2006).

Action observation, imitation and imagery therefore provide potentially powerful tools to prime movement within dance for people with PD via motor simulation, enabling access to known movement patterns or enhancing motor learning. This facilitation can be considered within the context of the relative preservation of associative networks in the basal ganglia, which underlie goaldirected movement control and may compensate for the diminished production of automatic movements (Redgrave et al., 2010). This is also evident in the facilitatory effects of external visual and auditory cues in people with PD (Spaulding et al., 2013; van Wegen et al., 2014). 
People with PD have shown the ability to imitate actions (for review, see Poliakoff, 2013), as well as exhibiting motor resonance for incidentally-observed (task-irrelevant) movements (Bek et al., 2018). They are also able to engage in motor imagery, reporting similar vividness to age-matched controls (Bek et al., 2019; Heremans et al., 2011). Several studies have demonstrated promising effects of interventions based on either observation or imagery in PD (see Abbruzzese et al., 2015; Caligiore et al., 2017). Combining observation and imagery has been shown to increase behavioural and neural effects in healthy individuals (Eaves et al., 2016), and there is some evidence that this combined approach may be effective in people with PD (Bek et al., 2019), but therapeutic benefits have not yet been tested.

Action observation, imagery and imitation are already frequently incorporated within dance programmes for people with PD. Indeed, several of the studies reviewed in this article refer explicitly to action representation processes, using terms such as "imagery", "mirroring", "visualization" or "mental rehearsal". In the sections below, we consider the involvement of imagery and visuallyevoked actions in sensorimotor, social and emotional effects of dance for people with PD. We then discuss the role of music and rhythm in dance and action representation.

Although other forms of exercise and creative activities also utilise action representations, in the present article we focus on dance as an emerging therapeutic approach for people with PD that has the potential to provide sustainable long-term benefits across multiple physical and non-physical domains.

\subsection{Sensorimotor effects of action observation and motor imagery}

Consistent with the broader literature on action observation, watching dance has been shown to activate sensorimotor cortical areas in the observer's brain, and the strength of this response is mediated by experience (Calvo-Merino et al., 2005; Cross et al., 2009, 2006). In healthy participants, increased neural activations have been found when actions are observed with the intention to 
imitate than with passive viewing (Grèzes et al., 1999). Therefore, when dance is observed in an active learning context (i.e., within a class), movement should be primed to a greater extent.

As noted above, external sensory cues can facilitate movement in people with PD. Seeing other people's movement provides another type of stimulus that may prime a broader range of actions than afforded by simple cueing, and a small number of studies have indicated effects of action observation in PD. People with PD have been found to exhibit motor resonance for simple hand actions - that is, their movements are automatically influenced by observing those of another person (Bek et al., 2018). They are also able to imitate the timing (Pelosin et al., 2010; Robles-Garcia et al., 2013) and amplitude (Bek et al., 2019) of observed actions. Thus, watching and imitating actions within dance is also likely to be effective in enhancing the timing and quality of movement in people with PD.

Moreover, action observation has been used in other therapeutic interventions for people with PD, demonstrating improvements in motor symptoms, balance and gait (Agosta et al., 2017; Pelosin et al., 2010), as well as increased functional independence (Buccino et al., 2011). There is also preliminary evidence that training with action observation can increase fronto-parietal brain activity in people with PD (Agosta et al., 2017). These findings suggest that, beyond the immediate facilitation of movement, action observation within dance may also confer therapeutic benefits over time.

Motor imagery is sometimes used explicitly in dance, but may also be evoked indirectly through the use of narrative or analogy, providing an implicit context in which to imagine visual and kinaesthetic properties of a movement. This could include the mechanics or qualities involved in a particular manner of moving (e.g., "move your arm like a swan"; Butt, 2017), or those afforded by an imagined object (e.g., weaving a thread; putting on a pair of boots). Evidence from healthy participants indicates that motor imagery may be enhanced by dance training: studies involving both novices (Sacco et al., 2006) and expert ballet dancers (Bar and DeSouza, 2016) have reported increased 
sensorimotor cortical activations during imagined movement following dance training combined with imagery practice.

People with PD are able to perform motor imagery of basic actions (e.g., Bek et al., 2019; Heremans et al., 2011), and motor imagery practice has shown positive effects within therapeutic interventions for PD (Kikuchi et al., 2014; Tamir et al., 2007). However, the processes underlying motor imagery may be compromised in PD, with neurophysiological evidence suggesting a greater reliance on compensatory networks involving visual processing areas (van Nuenen et al., 2012). Additionally, people with PD have shown a tendency to depict actions from a third-person (external) perspective rather than a first-person (internal) perspective when producing communicative gestures (Humphries et al., 2016), further indicating that they may be less likely to engage spontaneously in kinaesthetic imagery.

As noted above, observation and imagery are found to have stronger effects on movement when combined (Bek et al., 2016b; 2019; Eaves et al., 2016), and dance may promote the use of kinaesthetic imagery in people with PD by providing visual input through action observation, thereby reducing reliance on internally-generated action representations (Bek et al., 2019). References to imagined characters, objects or scenes within dance may also evoke both visual and kinaesthetic imagery, reducing the need for spontaneous generation of motor images.

To date, very few studies have examined effects of dance on imagery in people with PD, and findings are inconclusive. Improved performance on a task requiring mental rotation of body parts was found following participation in modern dance (Hashimoto et al., 2015), but an exercise group also showed improvement, so the effect cannot be specifically attributed to dance. Another study (Myers et al., 2018) found no change in neural activity during motor imagery of gait but, as noted above, the results were combined for participants receiving three different interventions (Tango, treadmill training, and stretching), which may have masked any dance-specific effects. 
If dance can improve motor imagery ability in people with PD, this could provide a strategy to facilitate movement in everyday life, thereby producing effects beyond dance classes. Indeed, qualitative evidence indicates that some individuals with PD use observation and imagery spontaneously for daily tasks (Bek et al., 2016a), and dance could encourage people with PD to apply these skills more broadly. Further to improving motor imagery ability in general, dance training may specifically increase the use of kinaesthetic imagery, as well as the utilisation of visual information provided by action observation to facilitate this.

\subsection{Emotional, social and psychological effects of action observation and motor imagery}

So far we have considered the influence of observation, imitation and imagery on movement, but the action observation system has also been proposed to have a role in social understanding and empathy (Chartrand and Bargh, 1999; lacoboni, 2005). For example, when we witness another person expressing a particular emotion, the same emotion may be embodied through our own neural and physiological response (Decety and Jackson, 2006). People with PD can have difficulty in recognizing emotions (Argaud et al., 2018), which may result from their own reduced facial expressiveness impacting on the ability to simulate others' emotions (e.g., Ricciardi et al., 2017). Additionally, communicative co-speech gestures may be altered in people with PD (Cleary et al., 2011; Humphries et al., 2016). Together, these issues can limit the ability to understand, empathise and communicate with others. Indeed, social cognition has been widely reported to be affected in PD (e.g., Narme et al., 2013), and difficulties with communication can impact significantly on wellbeing for people with PD (Wootton et al., 2018).

In healthy individuals, physiological responses (skin conductance) and subjective ratings of emotion when observing expressive movements have been found to be influenced by experience of dancing (Christensen et al., 2016), such that trained dancers were more sensitive than non-dancers to differences between movements expressing happiness and sadness. Moreover, dancers showed a 
closer correspondence between physiological measures and affective ratings. These findings demonstrate that dance training can enhance embodiment of observed actions, indicating the potential to improve emotional and social processing in people with PD.

Links to action representation, empathy and communication may be provided by aesthetic aspects of dance for people with PD, such as the use of story-telling and expression through movement (Westheimer, 2008). As noted above, themes and narratives within dance may encourage and facilitate the use of motor imagery. Additionally, practicing expressive gestures and facial movements in a group setting may enhance communicative action as well as increasing empathy through embodiment of emotions.

Dance often involves coordinating with others' movements and producing joint action, which relies on the ability to internally represent others' actions and either imitate or inhibit those movements as appropriate (Sebanz et al., 2006). This imitative control is also suggested to be important in social interaction (Spengler et al., 2010). Inhibitory control of action can be impaired in PD (Wylie et al., 2012), and the ability to inhibit imitation of observed actions may increase with disease severity (Bek et al., 2018). However, inhibitory processes can be improved with practice (e.g., Spierer et al., 2013). Group or partner work in dance may therefore contribute to not only increased social imitation (e.g., Heyes, 2013), but also improved inhibitory control and coordinative action (e.g., via turn-taking, leading and following), resulting in enhanced interaction and communication.

Dance has also been reported to provide psychological benefits for people with PD, such as improving confidence and motivation. Studies with older adults have highlighted the role of imagery in increasing self-efficacy and motivation in relation to physical activity (Kosteli et al., 2019; Wesch et al., 2006), suggesting another route by which imagery may contribute to functional outcomes of dance, as well as improving general well-being. 


\subsection{Music, rhythm, and action representation}

In addition to visual cues, external auditory cues such as music and rhythmic stimuli can aid motor control in PD. Music and rhythm are key components of many forms of dance, and also provide links to internal representations of action.

Music and rhythmic cues have been found to facilitate movement and timing in people with PD (for review see Ghai, Ghai, Schmitz, and Effenberg, 2018; Spaulding et al., 2013). For example, rhythmic auditory stimulation - a form of cueing that involves walking to music or a metronome beat - has been found to improve gait parameters as well as perceptual and motor timing in PD (Ashoori et al., 2015). The beneficial effects of music and rhythm are suggested to result from the activation of neural structures involved in movement and timing (Chen et al., 2008; Ghai et al., 2018), which may be accessed via alternative pathways associated with externally cued or goal-driven movement that bypass the affected basal ganglia circuitry, particularly premotor cortical areas (e.g., Hanakawa et al., 1999). However, beneficial effects are not consistently found, and it is likely that rhythm-based interventions need to be tailored to the individual (Ghai et al., 2018). Enhanced effects have been found when music was used to deliver rhythmic cueing, both in people with and without PD (Ghai et al., 2018; Rodger and Craig, 2016; Rose et al., 2019). Music provides a richer stimulus to elicit movement than simple rhythmic cues that rely more on intact timing mechanisms, and has been found to promote dopamine release in the basal ganglia (Salimpoor et al., 2011), activating neural networks involved in emotion and motivation (Ferreri et al., 2019). This process may contribute further to facilitatory effects on movement in people with PD (Pacchetti et al., 2000).

It has also been found that a population of "audiovisual" neurons in the brain are activated by action-relevant auditory stimuli (Kohler et al., 2002). Indeed, neuroimaging studies have shown that the motor system is engaged by music perception (Zatorre et al., 2007), and motor facilitation has been found in response to action-related sounds (Aziz-Zadeh et al., 2004). These findings suggest a 
route by which music and auditory cues may influence movement and emotion in a similar way to action observation (e.g., Overy and Molnar-Szakacs, 2009; Zatorre et al., 2007).

In the context of dance, music is therefore likely to boost the effects of action observation and imagery by providing an additional input into sensorimotor networks. For example, activity in the extrastriate body area, which is involved in action observation (e.g., Hardwick et al., 2018) has been found to be enhanced when dance movements were observed with accompanying music (Jola et al., 2013).

The effects of ecological action-sound cues have also been investigated in people with PD (Young et al., 2014). Walking to recorded footstep sounds reduced both temporal and spatial variability of gait, and step length variability improved more with this naturalistic stimulus than with metronome cueing. Moreover, participants demonstrated the ability to use motor imagery to regulate their step length after listening to the footstep cue, suggesting that this type of stimulus might be particularly effective by facilitating access to motor representations. Research in healthy participants has also shown that action-relevant auditory cues (footstep sounds) can influence the perception of one's own body (Tajadura-Jiménez et al., 2015), further indicating that movement characteristics may be altered via changes in imagined movement.

Westheimer (2008) notes that music and imagery in dance are intimately linked, and music has been used to support imagery of trained dance sequences in the absence of physical performance (e.g., Bar and DeSouza, 2016). Music may influence imagined movement and subsequent action execution in a number of ways. For example, a piece of music could be associated with a learned sequence (e.g., Rocha et al., 2017) or recall a particular movement pattern such as marching or swaying. Music may also evoke the imagined movement of an animal, object or natural substance (e.g., a gliding bird, a falling leaf, waves on the ocean), and it has been proposed that the motor system may be involved in representing these non-human movements (Schubotz, 2007). Music also supports 
storytelling and themes, and the combined use of storytelling and music in dance provides a particularly rich context to promote motor imagery.

\section{Future directions}

In this section we suggest directions for future research to increase understanding of action representation within dance for people with PD, and to identify how further benefits may be obtained within dance training or even through watching dance.

\subsection{Investigating action representation in dance for Parkinson's}

As noted above, studies in healthy participants have indicated effects of dance training on motor imagery (Bar and DeSouza, 2016; Sacco et al., 2006) and on physiological and neural responses to observed actions (Calvo-Merino et al., 2005; Christensen et al., 2016; Cross et al., 2006), but effects of dance on action representation have not yet been objectively demonstrated in people with PD. The investigation of changes relating to action observation, imitation and motor imagery in people with PD participating in dance therefore offers a promising avenue for future research. For example, motor imagery ability may be enhanced, or participants may learn to apply observation and imagery more effectively as strategies to facilitate movement for everyday tasks. These outcomes should be explored using both quantitative (e.g., neuroimaging) and qualitative (e.g., subjective reports of imagery use) measures, and could also be studied in relation to the explicit use of action representation processes within or alongside dance programmes. The relationship of sensorimotor and non-motor effects of dance in people with PD to changes in neural (e.g., sensorimotor activations during imagined movement) and behavioral (e.g., body rotation tasks) measures of motor imagery and action simulation could also be examined. 
Previous reviews have highlighted the need for further research into outcomes relating to social interaction (e.g., Lotzke et al., 2015). In particular, social-cognitive processes involving action representation could be assessed, such as emotion recognition, empathy and communicative gestures. Improvements in these processes could help people with PD to regain confidence and maintain social participation and interaction, but have received little attention in previous studies of dance and PD.

While the effects of music and rhythmic cues have been studied more broadly in people with PD, the influence of music on outcomes of dance for PD should also be explored, such as investigating the relationship between music, imagery and movement. In particular, music may enhance the effects of action observation, and promote and enhance motor imagery within dance classes. Music could also provide a cue outside of classes, evoking representations of associated actions or qualities of motion (e.g., Eitan and Granot, 2006) to facilitate movement.

Another consideration for future research is that different dance styles may vary in the extent to which imagery and observation are used, or the explicitness of action representation processes. For example, improvisational dance may rely less on action observation but may have a stronger emphasis on imagery, while partnered dance may involve a greater influence of touch rather than observation during learning. These differences and their relationships to physical, social and emotional outcomes of dance could therefore be investigated.

Effects of dance may also be mediated by individual differences in motor imagery ability, which are found both within the general population and among people with PD (Heremans et al., 2011; McAvinue and Robertson, 2008). Moreover, older people or those with neurological conditions may have greater difficulty in understanding and engaging with imagery tasks, because of cognitive impairments or reduced access to action representations (e.g., Emerson et al., 2018). These potential barriers could be addressed, respectively, by employing imagery more implicitly within 
dance programmes (e.g., through story-telling), or by providing additional education and instruction on imagery techniques.

Individual differences in motor experience and ability can also influence the effects of action observation. Cortical excitability and activation of sensorimotor neural networks are greater for observed movements that are more similar to those within the observer's own motor repertoire (e.g., Avanzino et al., 2015; Calvo-Merino et al., 2005); however, there is evidence that observational training can alter this neural response as new movements are learned, thus expanding the motor repertoire (Cross et al., 2009; Jola et al., 2012a; Lagravinese et al., 2017). To maximise potential benefits, individual motor abilities could therefore be taken into consideration when observation and imagery based exercises are practiced within dance.

\subsection{Watching dance: a potential investigative and therapeutic approach}

In this review we have discussed the role of action representation within dance and how observation, imitation and imagery may contribute to both motor and non-motor outcomes. A further suggestion is that, even without active participation, simply watching dance could offer therapeutic effects for people with PD. The term "kinaesthetic empathy" has been used in relation to dance and neuroaesthetics (Jola et al., 2012b; Reason and Reynolds, 2010), to describe a process of embodiment in which audiences may internally simulate the dancers' movements when watching a performance. Neuroimaging evidence has indicated the involvement of sensorimotor processes when watching dance (Calvo-Merino et al., 2008, 2005; Cross et al., 2009, 2006); moreover, experience in observing dance even without physical training can increase corticomotor responses to familiar dance movements (Jola et al., 2012a).

It should be noted that live observation - both for dance and other actions - has been found to increase sensorimotor activity compared with digital observation (Jola and Grosbras, 2013). Additionally, the social element of dance is important to people with PD (Houston \& McGill, 2013; 
Kunkel et al., 2018), and the group setting likely promotes greater use of imitation, coordination, and communicative and expressive action. Nonetheless, as discussed in Section 3.1, video-based action observation therapies have shown positive effects in people with PD. Training with observation and imagery of dance (i.e., watching videos while engaging in kinaesthetic imagery of the observed movements) may therefore provide a safe option for people with PD who are unable to attend classes, or could be used to supplement classes. In studies of Irish set dancing for people with PD, participants were asked to watch videos of the dance movements at home between classes (Shanahan et al., 2017; Volpe et al., 2013), and in the former study participants were asked to engage in "mental rehearsal" during home practice. However, in the absence of a comparison group taking dance classes without home practice, the influence of this additional training is unclear. Another potential avenue for further investigation is the use of virtual or augmented reality as a method of delivering dance training using observation and imitation (Abbasi, 2017; Lee et al., 2015). To date, one study has provided initial data suggesting sensorimotor and non-motor benefits of virtual reality imitation-based dance in a small number of people with PD (Lee et al., 2015), but further work is needed to determine the feasibility and efficacy of home-based training using digital and immersive technologies.

Investigating dance observation also allows for the use of techniques that would be difficult to apply during physical participation, such as neuroimaging and eye tracking, which may offer further insights into the effects of dance. Some of these approaches have already been used in research with healthy participants, and could also be explored in people with PD. As noted above, dance experience has been associated with increased cortical activations and emotional responses when observing dance and expressive movements (Calvo-Merino et al., 2005; Christensen et al., 2016; Cross et al., 2006). Additionally, eye movements can reveal what is attended to during action observation (e.g., the dancer's body or face, or other aspects of the scene) and to what extent movements are anticipated or predicted, potentially reflecting embodiment or motor simulation. For example, trained dancers have been found to exhibit shorter fixations and faster saccades (rapid 
directed eye movements) when watching dance, and to spend less time fixating the background of dance scenes (Stevens et al., 2010). Future research on observation of dance could therefore increase understanding of the effects of dance training on action representation in PD.

\section{Conclusions}

A growing number of studies indicate potential benefits of dance for people living with PD across motor and non-motor domains, but further work is needed to more clearly demonstrate the range of possible outcomes and to increase understanding of the mechanisms underlying these effects.

In this article we have considered how internal action representations may contribute to the beneficial effects of dance in people with PD. Evidence from various lines of investigation indicates that (i) action observation, imitation and motor imagery can facilitate movement in people with PD; (ii) dance can enhance motor imagery and embodiment in healthy participants; and (iii) action observation and imagery may contribute to physical and emotional effects of dance. Based on this evidence, we have proposed a role for action representation mechanisms in producing positive outcomes of dance for people with PD, and indeed that these processes may be enhanced through dance, allowing individuals to apply action observation and imagery more effectively in everyday situations beyond the dance class. We have also discussed links between music, rhythm and action representation, as well as how the aesthetic and expressive aspects of dance may utilise and enhance action representations.

Future research should explore the role of action representation within dance for people with PD and investigate related outcomes such as motor imagery, social-emotional cognition and communication, for different forms of dance. The relationship between action representation, music and movement in people with PD should also be explored, as well as longer-term outcomes in terms of neural changes in sensorimotor areas associated with action representation and transfer of skills to everyday tasks. 
Understanding action representation processes in dance for people with PD could indicate ways in which the benefits of dance may be further enhanced. These may include the incorporation of imagery and imitation within dance programmes, consideration of individual differences in action representation, or provision of additional imagery- and observation-based training to supplement classes or for those unable to attend.

It should be noted that, although the multidimensional nature of dance provides a rich context in which to study the effects of action representation in people with PD, action observation and motor imagery are embedded in many forms of sport, exercise, musical performance and other creative activities. While beyond the scope of the present review, the therapeutic potential of action representation within these other activities also warrants investigation.

Finally, beneficial effects of dance have also been found in other populations, such as healthy older adults and those with dementia (Kshtriya et al., 2015; McNeely et al., 2015a); research and practice in broader therapeutic applications of dance could therefore also be informed by consideration of action representation mechanisms.

\section{Acknowledgements}

This work was supported by funding from the Economic and Social Research Council [Grant Number ES/K013564/1 and Impact Acceleration Account award], and the Manchester Institute for Collaborative Research on Ageing.

We thank the participants of our pilot work and our collaborators at English National Ballet, who have contributed to some of the ideas presented in this paper.

\section{Declarations of interest: None}




\section{References}

Abbasi, J., 2017. Augmented reality takes Parkinson disease dance therapy out of the classroom. JAMA - J. Am. Med. Assoc. https://doi.org/10.1001/jama.2016.18122

Abbruzzese, G., Avanzino, L., Marchese, R., Pelosin, E., 2015. Action Observation and Motor Imagery: Innovative Cognitive Tools in the Rehabilitation of Parkinson's Disease. Parkinsons. Dis. https://doi.org/10.1155/2015/124214

Afshari, M., Yang, A., Bega, D., 2017. Motivators and Barriers to Exercise in Parkinson's Disease. J. Park. Dis. 7, 703-711. https://doi.org/10.3233/jpd-171173

Agosta, F., Gatti, R., Sarasso, E., Volonte, M.A., Canu, E., Meani, A., Sarro, L., Copetti, M., Cattrysse, E., Kerckhofs, E., Comi, G., Falini, A., Filippi, M., 2017. Brain plasticity in Parkinson's disease with freezing of gait induced by action observation training. J. Neurol. 264, 88-101. https://doi.org/10.1007/s00415-016-8309-7

Aguiar, L.P.C., Da Rocha, P.A., Morris, M., 2016. Therapeutic dancing for Parkinson's disease. Int. J. Gerontol. 10, 64-70. https://doi.org/10.1016/j.ijge.2016.02.002

Allen, J.L., McKay, J.L., Sawers, A., Hackney, M.E., Ting, L.H., 2017. Increased neuromuscular consistency in gait and balance after partnered, dance-based rehabilitation in parkinson's disease. J. Neurophysiol. https://doi.org/10.1152/jn.00813.2016

Argaud Soizic, Vérin Marc, Sauleau Paul, Grandjean Didier, 2018. Facial emotion recognition in Parkinson's disease: A review and new hypotheses. Mov. Disord. https://doi.org/10.1002/mds.27305

Ashoori, A., Eagleman, D.M., Jankovic, J., 2015. Effects of auditory rhythm and music on gait disturbances in Parkinson's disease. Front. Neurol. https://doi.org/10.3389/fneur.2015.00234

Aziz-Zadeh, L., Iacoboni, M., Zaidel, E., Wilson, S., Mazziotta, J., 2004. Left hemisphere motor 
facilitation in response to manual action sounds. Eur. J. Neurosci. https://doi.org/10.1111/j.0953-816X.2004.03348.x

Bar, R.J., DeSouza, J.F.X., 2016. Tracking plasticity: Effects of long-term rehearsal in expert dancers encoding music to movement. PLoS One. https://doi.org/10.1371/journal.pone.0147731

Batson, G., 2010. Feasibility of an intensive trial of modern dance for adults with parkinson disease. Complement. Health Pract. Rev. https://doi.org/10.1177/1533210110383903

Batson, G., Migliarese, S.J., Soriano, C., H. Burdette, J., Laurienti, P.J., 2014. Effects of improvisational dance on balance in Parkinson's disease: A two-phase fMRI case study. Phys. Occup. Ther. Geriatr. https://doi.org/10.3109/02703181.2014.927946

Bearss, K.A., McDonald, K.C., Bar, R.J., DeSouza, J.F.X., 2017. Improvements in balance and gait speed after a 12 week dance intervention for Parkinson's disease. Adv. Integr. Med. 4, 10-13. https://doi.org/10.1016/j.aimed.2017.02.002

Bek, J, Gowen, E., Vogt, S., Crawford, T., Poliakoff, E., 2018. Action observation produces motor resonance in Parkinson's disease. J. Neuropsychol. 12, 298-311. https://doi.org/10.1111/jnp.12133

Bek, J., Gowen, E., Vogt, S., Crawford, T.J., Poliakoff, E., 2019. Combined action observation and motor imagery influences hand movement amplitude in Parkinson's disease. Park. Relat. Disord. https://doi.org/10.1016/j.parkreldis.2018.11.001

Bek, Judith, Gowen, E., Vogt, S., Crawford, T.J., Poliakoff, E., 2018. Combined action observation and motor imagery influences hand movement amplitude in Parkinson's disease. Park. Relat. Disord. https://doi.org/10.1016/j.parkreldis.2018.11.001

Bek, J., Poliakoff, E., Marshall, H., Trueman, S., Gowen, E., 2016a. Enhancing voluntary imitation through attention and motor imagery. Exp. Brain Res. 234. https://doi.org/10.1007/s00221016-4570-3 
Bek, J., Webb, J., Gowen, E., Vogt, S., Crawford, T.J., Sullivan, M.S., Poliakoff, E., 2016b. Patients' Views on a Combined Action Observation and Motor Imagery Intervention for Parkinson's Disease. Parkinsons. Dis. 2016. https://doi.org/10.1155/2016/7047910

Blandy, L.M., Beevers, W.A., Fitzmaurice, K., Morris, M.E., 2015. Therapeutic Argentine tango dancing for people with mild Parkinson's disease: A feasibility study. Front. Neurol. https://doi.org/10.3389/fneur.2015.00122

Blasing, B., Calvo-Merino, B., Cross, E.S., Jola, C., Honisch, J., Stevens, C.J., 2012. Neurocognitive control in dance perception and performance. Acta Psychol. (Amst). 139, 300-308. https://doi.org/10.1016/j.actpsy.2011.12.005

Bognar, S., DeFaria, A.M., O’Dwyer, C., Pankiw, E., Simic Bogler, J., Teixeira, S., Nyhof-Young, J., Evans, C., 2017. More than just dancing: experiences of people with Parkinson's disease in a therapeutic dance program. Disabil. Rehabil. https://doi.org/10.1080/09638288.2016.1175037

Brown, R.G., Marsden, C.D., 1988. INTERNAL VERSUS EXTERNAL CUES AND THE CONTROL OF $\begin{array}{lllll}\text { ATTENTION IN } & \text { PARKINSONS-DISEASE. } & \text { Brain } & 111, & 323-345 .\end{array}$ https://doi.org/10.1093/brain/111.2.323

Buccino, G., Gatti, R., Giusti, M.C., Negrotti, A., Rossi, A., Calzetti, S., Cappa, S.F., 2011. Action Observation Treatment Improves Autonomy in Daily Activities in Parkinson's Disease Patients: Results from a Pilot Study. Mov. Disord. 26, 1963-1964. https://doi.org/10.1002/mds.23745

Buccino, G., Vogt, S., Ritzl, A., Fink, G.R., Zilles, K., Freund, H.J., Rizzolatti, G., 2004. Neural circuits underlying imitation learning of hand actions: An event-related fMRI study. Neuron 42, 323334. https://doi.org/10.1016/s0896-6273(04)00181-3

Butt, C.A., 2017. "move your arm like a swan" dance for pd demedicalizes Parkinson disease. JAMA J. Am. Med. Assoc. https://doi.org/10.1001/jama.2016.21033

Caligiore, D, Mustile, M., Spalletta, G., Baldassarre, G., 2017. Action observation and motor imagery 
for rehabilitation in Parkinson's disease: A systematic review and an integrative hypothesis. Neurosci. Biobehav. Rev. 72, 210-222. https://doi.org/10.1016/j.neubiorev.2016.11.005

Caligiore, Daniele, Mustile, M., Spalletta, G., Baldassarre, G., 2017. Action observation and motor imagery for rehabilitation in Parkinson's disease: A systematic review and an integrative $\begin{array}{llll}\text { hypothesis. } & \text { Neurosci. } & \text { Biobehav. } & \text { Rev. }\end{array}$ https://doi.org/10.1016/j.neubiorev.2016.11.005

Calvo-Merino, B., Glaser, D.E., Grezes, J., Passingham, R.E., Haggard, P., 2005. Action observation and acquired motor skills: An fMRI study with expert dancers. Cereb. Cortex 15, 1243-1249. https://doi.org/10.1093/cercor/bhi007

Calvo-Merino, B., Jola, C., Glaser, D.E., Haggard, P., 2008. Towards a sensorimotor aesthetics of performing art. Conscious. Cogn. https://doi.org/10.1016/j.concog.2007.11.003

Caspers, S., Zilles, K., Laird, A.R., Eickhoff, S.B., 2010. ALE meta-analysis of action observation and imitation in the human brain. Neuroimage 50, 1148-1167. https://doi.org/10.1016/j.neuroimage.2009.12.112

Chartrand, T.L., Bargh, J.A., 1999. The Chameleon effect: The perception-behavior link and social interaction. J. Pers. Soc. Psychol. 76, 893-910. https://doi.org/10.1037//0022-3514.76.6.893

Chaudhuri, K.R., Healy, D.G., Schapira, A.H.V., 2006. Non-motor symptoms of Parkinson's disease: Diagnosis and management. Lancet Neurol. https://doi.org/10.1016/S1474-4422(06)70373-8

Chen, J.L., Penhune, V.B., Zatorre, R.J., 2008. Moving on time: Brain network for auditory-motor synchronization is modulated by rhythm complexity and musical training. J. Cogn. Neurosci. https://doi.org/10.1162/jocn.2008.20018

Christensen, J.F., Gomila, A., Gaigg, S.B., Sivarajah, N., Calvo-Merino, B., 2016. Dance Expertise Modulates Behavioral and Psychophysiological Responses to Affective Body Movement. J. Exp. Psychol. Percept. Perform. 42, 1139-1147. https://doi.org/10.1037/xhp0000176 
Cleary, R.A., Poliakoff, E., Galpin, A., Dick, J.P.R., Holler, J., 2011. An investigation of co-speech gesture production during action description in Parkinson's disease. Parkinsonism Relat. Disord. 17, 753-756. https://doi.org/10.1016/j.parkreldis.2011.08.001

Cross, E.S., Hamilton, A.F. d. C., Grafton, S.T., 2006. Building a motor simulation de novo: Observation of dance by Neuroimage. https://doi.org/10.1016/j.neuroimage.2006.01.033

Cross, E.S., Kraemer, D.J.M., Hamilton, A.F.D., Kelley, W.M., Grafton, S.T., 2009. Sensitivity of the Action Observation Network to Physical and Observational Learning. Cereb. Cortex 19, 315326. https://doi.org/10.1093/cercor/bhn083

De Natale, E.R., Paulus, K.S., Aiello, E., Sanna, B., Manca, A., Sotgiu, G., Leali, P.T., Deriu, F., 2017. Dance therapy improves motor and cognitive functions in patients with Parkinson's disease. NeuroRehabilitation. https://doi.org/10.3233/NRE-161399

Decety, J., Jackson, P.L., 2006. A social-neuroscience perspective on empathy. Curr. Dir. Psychol. Sci. 15, 54-58. https://doi.org/10.1111/j.0963-7214.2006.00406.x

Delextrat, A., Bateman, J., Esser, P., Targen, N., Dawes, H., 2016. The potential benefits of Zumba Gold in people with mild-to-moderate Parkinson's: Feasibility and effects of dance styles and number of sessions. Complement. Ther. Med. 27, 68-73. https://doi.org/10.1016/j.ctim.2016.05.009

Dhami, P., Moreno, S., DeSouza, J.F.X., 2015. New framework for rehabilitation - fusion of cognitive and physical rehabilitation: the hope for dancing. Front. Psychol. 5. https://doi.org/10.3389/fpsyg.2014.01478

dos Santos Delabary, M., Komeroski, I.G., Monteiro, E.P., Costa, R.R., Haas, A.N., 2018. Effects of dance practice on functional mobility, motor symptoms and quality of life in people with Parkinson's disease: a systematic review with meta-analysis. Aging Clin. Exp. Res. 
https://doi.org/10.1007/s40520-017-0836-2

Duncan, R.P., Earhart, G.M., 2014. Are the Effects of Community-Based Dance on Parkinson Disease Severity, Balance, and Functional Mobility Reduced with Time? A 2-Year Prospective Pilot Study. J. Altern. Complement. Med. 20, 757-763. https://doi.org/10.1089/acm.2012.0774

Duncan, Ryan P., Earhart, G.M., 2012. Randomized controlled trial of community-based dancing to modify disease progression in Parkinson disease. Neurorehabil. Neural Repair. https://doi.org/10.1177/1545968311421614

Duncan, R P, Earhart, G.M., 2012. Randomized Controlled Trial of Community-Based Dancing to Modify Disease Progression in Parkinson Disease. Neurorehabil. Neural Repair 26, 132-143. https://doi.org/10.1177/1545968311421614

Eaves, D.L., Riach, M., Holmes, P.S., Wright, D.J., 2016. Motor Imagery during Action Observation: A Brief Review of Evidence, Theory and Future Research Opportunities. Front. Neurosci. 10. https://doi.org/10.3382/fnins.2015.00514

Eitan, Z., Granot, R.Y., 2006. How music moves: Musical parameters and listeners' images of motion. Music Percept. https://doi.org/10.1525/mp.2006.23.3.221

Emerson, J.R., Binks, J.A., Scott, M.W., Ryan, R.P., Eaves, D.L., 2018. Combined action observation and motor imagery therapy: A novel method for post-stroke motor rehabilitation. AIMS Neurosci. https://doi.org/10.3934/NEUROSCIENCE.2018.4.236

Ferreri, L., Mas-Herrero, E., Zatorre, R.J., Ripollés, P., Gomez-Andres, A., Alicart, H., Olivé, G., MarcoPallarés, J., Antonijoan, R.M., Valle, M., Riba, J., Rodriguez-Fornells, A., 2019. Dopamine modulates the reward experiences elicited by music. Proc. Natl. Acad. Sci. U. S. A. https://doi.org/10.1073/pnas.1811878116

Foltynie, T., Langston, J.W., 2018. Therapies to slow, stop, or reverse Parkinson's disease. J. Parkinsons. Dis. https://doi.org/10.3233/JPD-181481 
Foster, E.R., Golden, L., Duncan, R.P., Earhart, G.M., 2013. Community-based argentine tango dance program is associated with increased activity participation among individuals with parkinson's disease. Arch. Phys. Med. Rehabil. https://doi.org/10.1016/j.apmr.2012.07.028

Ghai, S., Ghai, I., Schmitz, G., Effenberg, A.O., 2018. Effect of rhythmic auditory cueing on parkinsonian gait: A systematic review and meta-analysis. Sci. Rep. https://doi.org/10.1038/s41598-017-16232-5

Goetz, C.G., Tilley, B.C., Shaftman, S.R., Stebbins, G.T., Fahn, S., Martinez-Martin, P., Poewe, W., Sampaio, C., Stern, M.B., Dodel, R., Dubois, B., Holloway, R., Jankovic, J., Kulisevsky, J., Lang, A.E., Lees, A., Leurgans, S., LeWitt, P.A., Nyenhuis, D., Olanow, C.W., Rascol, O., Schrag, A., Teresi, J.A., van Hilten, J.J., LaPelle, N., Agarwal, P., Athar, S., Bordelan, Y., Bronte-Stewart, H.M., Camicioli, R., Chou, K., Cole, W., Dalvi, A., Delgado, H., Diamond, A., Dick, J.P., Duda, J., Elble, R.J., Evans, C., Evidente, V.G., Fernandez, H.H., Fox, S., Friedman, J.H., Fross, R.D., Gallagher, D., Goetz, C.G., Hall, D., Hermanowicz, N., Hinson, V., Horn, S., Hurtig, H., Kang, U.J., Kleiner-Fisman, G., Klepitskaya, O., Kompoliti, K., Lai, E.C., Leehey, M.L., Leroi, I., Lyons, K.E., McClain, T., Metzer, S.W., Miyasaki, J., Morgan, J.C., Nance, M., Nemeth, J., Pahwa, R., Parashos, S.A., Schneider, J.S.J.S., Schrag, A., Sethi, K., Shulman, L.M., Siderowf, A., Silverdale, M., Simuni, T., Stacy, M., Stern, M.B., Stewart, R.M., Sullivan, K., Swope, D.M., Wadia, P.M., Walker, R.W., Walker, R., Weiner, W.J., Wiener, J., Wilkinson, J., Wojcieszek, J.M., Wolfrath, S., Wooten, F., Wu, A., Zesiewicz, T.A., Zweig, R.M., 2008. Movement Disorder Society-Sponsored Revision of the Unified Parkinson's Disease Rating Scale (MDS-UPDRS): Scale presentation and clinimetric testing results. Mov. Disord. https://doi.org/10.1002/mds.22340

Golomer, E., Bouillette, A., Mertz, C., Keller, J., 2008. Effects of mental imagery styles on shoulder and hip rotations during preparation of pirouettes. J. Mot. Behav. 40, 281-290. https://doi.org/10.3200/JMBR.40.4.281-290

Grèzes, J., Costes, N., Decety, J., 1999. The effects of learning and intention on the neural network 
involved in the perception of meaningless actions. Brain. https://doi.org/10.1093/brain/122.10.1875

Guillot, A., Collet, C., Nguyen, V.A., Malouin, F., Richards, C., Doyon, J., 2009. Brain Activity During Visual Versus Kinesthetic Imagery: An fMRI Study. Hum. Brain Mapp. 30, 2157-2172. https://doi.org/10.1002/hbm.20658

Hackney, M.E., Earhart, G.M., 2010. Effects of Dance on Gait and Balance in Parkinson's Disease: A Comparison of Partnered and Nonpartnered Dance Movement. Neurorehabil. Neural Repair 24, 384-392. https://doi.org/10.1177/1545968309353329

Hackney, M E, Earhart, G.M., 2009. Short duration, intensive tango dancing for Parkinson disease: An uncontrolled pilot study. Complement. Ther. Med. 17, 203-207. https://doi.org/10.1016/j.ctim.2008.10.005

Hackney, Madeleine E., Earhart, G.M., 2009a. Health-related quality of life and alternative forms of $\begin{array}{llll}\text { exercise in Parkinson disease. Park. Relat. Disord. } & \text {. }\end{array}$ https://doi.org/10.1016/j.parkreldis.2009.03.003

Hackney, Madeleine E., Earhart, G.M., 2009b. Effects of dance on movement control in Parkinson's disease: A comparison of Argentine tango and American ballroom. J. Rehabil. Med. https://doi.org/10.2340/16501977-0362

Hackney, M.E., Kantorovich, S., Levin, R., Earhart, G.M., 2007. Effects of tango on functional mobility in parkinson's disease: A preliminary study. J. Neurol. Phys. Ther. https://doi.org/10.1097/NPT.0b013e31815ce78b

Hanakawa, T., Fukuyama, H., Katsumi, Y., Honda, M., Shibasaki, H., 1999. Enhanced lateral premotor activity during paradoxical gait in parkinson's disease. Ann. Neurol. https://doi.org/10.1002/1531-8249(199903)45:3<329::AID-ANA8>3.0.CO;2-S

Hardwick, R.M., Caspers, S., Eickhoff, S.B., Swinnen, S.P., 2018. Neural correlates of action: 
Comparing meta-analyses of imagery, observation, and execution. Neurosci. Biobehav. Rev. https://doi.org/10.1016/j.neubiorev.2018.08.003

Hashimoto, H., Takabatake, S., Miyaguchi, H., Nakanishi, H., Naitou, Y., 2015. Effects of dance on motor functions, cognitive functions, and mental symptoms of Parkinson's disease: A quasirandomized pilot trial. Complement. Ther. Med. https://doi.org/10.1016/j.ctim.2015.01.010

Heiberger, L., Maurer, C., Amtage, F., Mendez-Balbuena, I., Schulte-Mönting, J., Hepp-Reymond, M.C., Kristeva, R., 2011. Impact of a weekly dance class on the functional mobility and on the quality of life of individuals with Parkinson's disease. Front. Aging Neurosci. https://doi.org/10.3389/fnagi.2011.00014

Heremans, E., Feys, P., Nieuwboer, A., Vercruysse, S., Vandenberghe, W., Sharma, N., Helsen, W., 2011. Motor Imagery Ability in Patients With Early- and Mid-Stage Parkinson Disease. Neurorehabil. Neural Repair 25, 168-177. https://doi.org/10.1177/1545968310370750

Heyes, C. M., 2013. What can imitation do for cooperation? In: Calcott B, Joyce R, Stereiny K, editors. Signalling, Commitment and Emotion: MIT Press.

Hou, L., Chen, W., Liu, X., Qiao, D., Zhou, F.M., 2017. Exercise-induced neuroprotection of the nigrostriatal dopamine system in Parkinson's disease. Front. Aging Neurosci. https://doi.org/10.3389/fnagi.2017.00358

Houston, S., McGill, A., 2013. A mixed-methods study into ballet for people living with Parkinson's. Arts Health 5, 103-119. https://doi.org/10.1080/17533015.2012.745580

Humphries, S, Holler, J., Crawford, T.J., Herrera, E., Polialzoff, E., 2016. A third-person perspective on co-speech action gestures in Parkinson's disease. Cortex 78, 44-54. https://doi.org/10.1016/j.cortex.2016.02.009

lacoboni, M., 2005. Neural mechanisms of imitation. Curr. Opin. Neurobiol. 15, 632-637. https://doi.org/10.1016/j.conb.2005.10.010 
Jola, C., Abedian-Amiri, A., Kuppuswamy, A., Pollick, F.E., Grosbras, M.H., 2012a. Motor simulation without motor expertise: Enhanced corticospinal excitability in visually experienced dance spectators. PLoS One. https://doi.org/10.1371/journal.pone.0033343

Jola, C., Davis, A., Haggard, P., 2011. Proprioceptive integration and body representation: Insights into dancers' expertise. Exp. Brain Res. https://doi.org/10.1007/s00221-011-2743-7

Jola, C., Ehrenberg, S., Reynolds, D., 2012b. The experience of watching dance: Phenomenologicalneuroscience duets. Phenomenol. Cogn. Sci. https://doi.org/10.1007/s11097-010-9191-x

Jola, C., Grosbras, M.H., 2013. In the here and now: Enhanced motor corticospinal excitability in novices when watching live compared to video recorded dance. Cogn. Neurosci. https://doi.org/10.1080/17588928.2013.776035

Jola, C., McAleer, P.M.A.P., Grosbras, M.H., Love, S.A., Morison, G., Pollick, F.E., 2013. Uni-and multisensory brain areas are synchronised across spectators when watching unedited dance recordings. Iperception. https://doi.org/10.1068/i0536

Kalyani, H.H.N., Sullivan, K., Moyle, G., Brauer, S., Jeffrey, E.R., Roeder, L., Berndt, S., Kerr, G., 2019. Effects of Dance on Gait, Cognition, and Dual-Tasking in Parkinson's Disease: A Systematic Review and Meta-Analysis. J. Parkinsons. Dis. https://doi.org/10.3233/JPD-181516

Karlsen, K.H., Tandberg, E., Årsland, D., Larsen, J.P., 2000. Health related quality of life in Parkinson's disease: A prospective longitudinal study. J. Neurol. Neurosurg. Psychiatry. https://doi.org/10.1136/jnnp.69.5.584

Kikuchi, A., Baba, T., Hasegawa, T., Sugeno, N., Konno, M., Miura, E., Oshima, R., Aoki, M., Takeda, A., 2014. Improvement of freezing of gait in patients with Parkinson's disease by imagining bicycling. Case Rep. Neurol. 6, 92-95. https://doi.org/10.1159/000362119

Kleiner-Fisman, G., Gryfe, P., Naglie, G., 2013. A Patient-Based Needs Assessment for Living Well with Parkinson Disease: Implementation via Nominal Group Technique. Parkinsons. Dis. 2013, 
974964. https://doi.org/10.1155/2013/974964

Kohler, E., Keysers, C., Umilta, M.A., Fogassi, L., Gallese, V., Rizzolatti, G., 2002. Hearing sounds, understanding actions: Action representation in mirror neurons. Science (80-. ). https://doi.org/10.1126/science.1070311

Kosteli, M.-C., Williams, S.E., Cumming, J., 2019. Exploring Imagery as a Technique for Promoting Physical Activity in Older Adults. Imagin. Cogn. Pers. https://doi.org/10.1177/0276236618767083

Kshtriya, S., Barnstaple, R., Rabinovich, D.B., DeSouza, J.F.X., 2015. Dance and Aging: A Critical Review of Findings in Neuroscience, American Journal of Dance Therapy. https://doi.org/10.1007/s10465-015-9196-7

Kunkel, D., Robison, J., Fitton, C., Hulbert, S., Roberts, L., Wiles, R., Pickering, R., Roberts, H., Ashburn, A., 2018. It takes two: the influence of dance partners on the perceived enjoyment and benefits during participation in partnered ballroom dance classes for people with Parkinson's. Disabil. Rehabil. 40. https://doi.org/10.1080/09638288.2017.1323029

Lagravinese, G., Bisio, A., Ruggeri, P., Bove, M., Avanzino, L., 2017. Learning by observing: the effect of multiple sessions of action-observation training on the spontaneous movement tempo and motor resonance. Neuropsychologia. https://doi.org/10.1016/j.neuropsychologia.2016.09.022

Lee, N.-Y., Lee, D.-K., Song, H.-S., 2015. Effect of virtual reality dance exercise on the balance, activities of daily living, and depressive disorder status of Parkinson's disease patients. J. Phys. Ther. Sci. https://doi.org/10.1589/jpts.27.145

Lewis, C., Annett, L.E., Davenport, S., Hall, A.A., Lovatt, P., 2016. Mood changes following social dance sessions in people with Parkinson's disease. J. Health Psychol. https://doi.org/10.1177/1359105314529681

Lotzke, D., Ostermann, T., Bussing, A., 2015. Argentine tango in Parkinson disease - a systematic 
review and meta-analysis. Bmc Neurol. 15. https://doi.org/10.1186/s12883-015-0484-0

Mandelbaum, R., Lo, A.C., 2014. Examining Dance as an Intervention in Parkinson's Disease: A Systematic Review. Am. J. Danc. Ther. https://doi.org/10.1007/s10465-014-9181-6

Marchant, D., Sylvester, J.L., Earhart, G.M., 2010. Effects of a short duration, high dose contact improvisation dance workshop on Parkinson disease: A pilot study. Complement. Ther. Med. 18, 184-190. https://doi.org/10.1016/j.ctim.2010.07.004

McAvinue, L.P., Robertson, I.H., 2008. Measuring motor imagery ability: A review. Eur. J. Cogn. Psychol. 20, 232-251. https://doi.org/10.1080/09541440701394624

McKay, J.L., Ting, L.H., Hackney, M.E., 2016. Balance, body motion, and muscle activity after highvolume short-term dance-based rehabilitation in persons with Parkinson disease: A pilot study. J. Neurol. Phys. Ther. https://doi.org/10.1097/NPT.0000000000000150

McKee, K.E., Hackney, M.E., 2013. The effects of adapted tango on spatial cognition and disease severity in parkinson's disease. J. Mot. Behav. 45, 519-529. https://doi.org/10.1080/00222895.2013.834288

McNeely, M. E., Duncan, R.P., Earhart, G.M., 2015. Impacts of dance on non-motor symptoms, participation, and quality of life in Parkinson disease and healthy older adults. Maturitas 82, 336-341. https://doi.org/10.1016/j.maturitas.2015.08.002

McNeely, Marie E., Mai, M.M., Duncan, R.P., Earhart, G.M., 2015. Differential effects of tango versus dance for PD in Parkinson disease. Front. Aging Neurosci. 7, 1-8. https://doi.org/10.3389/fnagi.2015.00239

Myers, P.S., McNeely, M.E., Pickett, K.A., Duncan, R.P., Earhart, G.M., 2018. Effects of exercise on gait and motor imagery in people with Parkinson disease and freezing of gait. Park. Relat. Disord. https://doi.org/10.1016/j.parkreldis.2018.05.006

Narme, P., Mouras, H., Roussel, M., Duru, C., Krystkowiak, P., Godefroy, O., 2013. Emotional and 
cognitive social processes are impaired in parkinson's disease and are related to behavioral disorders. Neuropsychology. https://doi.org/10.1037/a0031522

Nimwegen, M. Van, Speelman, A.D., Hofman-Van Rossum, E.J.M., Overeem, S., Deeg, D.J.H., Borm, G.F., Van Der Horst, M.H.L., Bloem, B.R., Munneke, M., 2011. Physical inactivity in Parkinson's disease. J. Neurol. https://doi.org/10.1007/s00415-011-6097-7

Nordin, S.M., Cumming, J., 2008. Exploring common ground: Comparing the imagery of dancers and aesthetic sport performers. J. Appl. Sport Psychol. 20, 375-391. https://doi.org/10.1080/10413200802210795

Nordin, S.M., Cumming, J., 2006. The Development of Imagery in Dance. J. Danc. Med. Sci.

Overy, K., Molnar-Szakacs, I., 2009. Being Together in Time: Musical Experience and the Mirror Neuron System. Music Percept. https://doi.org/10.1525/mp.2009.26.5.489

Pacchetti, C., Mancini, F., Aglieri, R., Fundaró, C., Martignoni, E., Nappi, G., 2000. Active music therapy in Parkinson's disease: An integrative method for motor and emotional rehabilitation. Psychosom. Med. https://doi.org/10.1097/00006842-200005000-00012

Pelosin, E., Avanzino, L., Bove, M., Stramesi, P., Nieuwboer, A., Abbruzzese, G., 2010. Action Observation Improves Freezing of Gait in Patients With Parkinson's Disease. Neurorehabil. Neural Repair 24, 746-752. https://doi.org/10.1177/1545968310368685

Peto, V., Jenkinson, C., Fitzpatrick, R., Greenhall, R., 1995. The development and validation of a short measure of functioning and well being for individuals with Parkinson's disease. Qual. Life Res. https://doi.org/10.1007/BF02260863

Poliakoff, E., 2013. Representation of action in Parkinson's disease: Imagining, observing, and naming actions. J. Neuropsychol. 7, 241-254. https://doi.org/10.1111/jnp.12005

Rabinovich, D., DeSouza, J., Arakaki, T., Rodriguez Quiroga, S., Litvak, V., Firmani, J., Garreto, N., 2017. Intensive Short-Term Dance Intervention in Parkinson's Disease. Mov Disord.2017. 32 
(S2).

Rawson, K.S., McNeely, M.E., Duncan, R.P., Pickett, K.A., Perlmutter, J.S., Earhart, G.M., 2019. Exercise and Parkinson Disease: Comparing Tango, Treadmill, and Stretching. J. Neurol. Phys. Ther. https://doi.org/10.1097/NPT.0000000000000245

Reason, M., Reynolds, D., 2010. Kinesthesia, empathy, and related pleasures: An inquiry into audience experiences of watching dance. Danc. Res. J. https://doi.org/10.1017/S0149767700001030

Redgrave, P., Rodriguez, M., Smith, Y., Rodriguez-Oroz, M.C., Lehericy, S., Bergman, H., Agid, Y., DeLong, M.R., Obeso, J.A., 2010. Goal-directed and habitual control in the basal ganglia: implications for Parkinson's disease. Nat. Rev. Neurosci. 11, 760-772. https://doi.org/10.1038/nrn2915

Ricciardi, L., Visco-Comandini, F., Erro, R., Morgante, F., Bologna, M., Fasano, A., Ricciardi, D., Edwards, M.J., Kilner, J., 2017. Facial emotion recognition and expression in Parkinson's disease: An emotional mirror mechanism? PLoS One. https://doi.org/10.1371/journal.pone.0169110

Rios Romenets, S., Anang, J., Fereshtehnejad, S.M., Pelletier, A., Postuma, R., 2015. Tango for treatment of motor and non-motor manifestations in Parkinson's disease: A randomized control study. Complement. Ther. Med. https://doi.org/10.1016/j.ctim.2015.01.015

Rizzolatti, G., Sinigaglia, C., 2010. The functional role of the parieto-frontal mirror circuit: Interpretations and misinterpretations. Nat. Rev. Neurosci. https://doi.org/10.1038/nrn2805

Robles-Garcia, V., Arias, P., Sanmartin, G., Espinosa, N., Flores, J., Grieve, K.L., Cudeiro, J., 2013. Motor facilitation during real-time movement imitation in Parkinson's disease: A virtual reality $\begin{array}{lllll}\text { study. } & \text { Parkinsonism } & \text { Relat. } & \text { Disord. } & 19,\end{array}$ https://doi.org/10.1016/j.parkreldis.2013.08.005 
Rocha, P.A., Slade, S.C., McClelland, J., Morris, M.E., 2017. Dance is more than therapy: Qualitative analysis on therapeutic dancing classes for Parkinson's. Complement. Ther. Med. 34. https://doi.org/10.1016/j.ctim.2017.07.006

Rodger, M.W.M., Craig, C.M., 2016. Beyond the Metronome: Auditory Events and Music May Afford More than Just Interval Durations as Gait Cues in Parkinson's Disease. Front. Neurosci. https://doi.org/10.3389/fnins.2016.00272

Sacco, K., Cauda, F., Cerliani, L., Mate, D., Duca, S., Geminiani, G.C., 2006. Motor imagery of walking following training in locomotor attention. The effect of "the tango lesson." Neuroimage 32, 1441-1449. https://doi.org/10.1016/j.neuroimage.2006.05.018

Salimpoor, V.N., Benovoy, M., Larcher, K., Dagher, A., Zatorre, R.J., 2011. Anatomically distinct dopamine release during anticipation and experience of peak emotion to music, in: Nature Neuroscience. https://doi.org/10.1038/nn.2726

Sara Houston, B., McGill, A., Raymond Lee, with, Watkins MCSP, K., Donald, C., 2015. English National Ballet, Dance for Parkinson's: An Investigative Study 2 A report on a three-year mixed methods research study.

Schubotz, R.I., 2007. Prediction of external events with our motor system: towards a new framework. Trends Cogn. Sci. https://doi.org/10.1016/j.tics.2007.02.006

Schuster, C., Hilfiker, R., Amft, O., Scheidhauer, A., Andrews, B., Butler, J., Kischka, U., Ettlin, T., 2011. Best practice for motor imagery: a systematic literature review on motor imagery training elements in five different disciplines. Bmc Med. 9. https://doi.org/10.1186/1741-7015-9-75

Sebanz, N., Bekkering, H., Knoblich, G., 2006. Joint action: bodies and minds moving together. Trends Cogn. Sci. https://doi.org/10.1016/j.tics.2005.12.009

Shanahan, 2015. Dance for People With Parkinson Disease: What Is the Evidence Telling Us? (vol 96, pg 141, 2015). Arch. Phys. Med. Rehabil. 96, 1931. https://doi.org/10.1016/j.apmr.2015.08.420 
Shanahan, J., Morris, M.E., Bhriain, O.N., Volpe, D., Richardson, M., Clifford, A.M., 2015. Is Irish set dancing feasible for people with Parkinson's disease in Ireland? Complement. Ther. Clin. Pract. https://doi.org/10.1016/j.ctcp.2014.12.002

Sharp, K., Hewitt, J., 2014. Dance as an intervention for people with Parkinson's disease: A systematic review and meta-analysis. Neurosci. Biobehav. Rev. 47, 445-456. https://doi.org/10.1016/j.neubiorev.2014.09.009

Spaulding, S.J., Barber, B., Colby, M., Cormack, B., Mick, T., Jenkins, M.E., 2013. Cueing and Gait Improvement Among People With Parkinson's Disease: A Meta-Analysis. Arch. Phys. Med. Rehabil. 94, 562-570. https://doi.org/10.1016/j.apmr.2012.10.026

Spengler, S., Bird, G., Brass, M., 2010. Hyperimitation of Actions Is Related to Reduced Understanding of Others' Minds in Autism Spectrum Conditions. Biol. Psychiatry 68, 11481155. https://doi.org/10.1016/j.biopsych.2010.09.017

Spierer, L., Chavan, C.F., Manuel, A.L., 2013. Training-induced behavioral and brain plasticity in inhibitory control. Front. Hum. Neurosci. https://doi.org/10.3389/fnhum.2013.00427

Stefan, K., Classen, J., Celnik, P., Cohen, L.G., 2008. Concurrent action observation modulates practice-induced motor memory formation. Eur. J. Neurosci. 27, 730-738. https://doi.org/10.1111/j.1460-9568.2008.06035.x

Stevens, C., Winskel, H., Howell, C., Vidal, L.-M., Latimer, C., Milne-Home, J., 2010. Perceiving dance: schematic expectations guide experts' scanning of a contemporary dance film. J. Dance Med. Sci.

Tajadura-Jiménez, A., Basia, M., Deroy, O., Fairhurst, M., Marquardt, N., Bianchi-Berthouze, N., 2015. As light as your footsteps: Altering walking sounds to change perceived body weight, emotional state and gait, in: Conference on Human Factors in Computing Systems - Proceedings. https://doi.org/10.1145/2702123.2702374 
Tamir, R., Dickstein, R., Huberman, M., 2007. Integration of motor imagery and physical practice in group treatment applied to subjects with Parkinson's disease. Neurorehabil. Neural Repair 21, 68-75. https://doi.org/10.1177/1545968306292608

van Nuenen, B.F.L., Helmich, R.C., Buenen, N., van de Warrenburg, B.P.C., Bloem, B.R., Toni, I., 2012. Compensatory Activity in the Extrastriate Body Area of Parkinson's Disease Patients. J. Neurosci. 32, 9546-9553. https://doi.org/10.1523/jneurosci.0335-12.2012

van Wegen, E.E.H., Hirsch, M.A., Huiskamp, M., Kwakkel, G., 2014. Harnessing Cueing Training for Neuroplasticity in Parkinson Disease. Top. Geriatr. Rehabil. 30, 46-57. https://doi.org/10.1097/tgr.0000000000000005

Ventura, M.I., Barnes, D.E., Ross, J.M., Lanni, K.E., Sigvardt, K.A., Disbrow, E.A., 2016. A pilot study to evaluate multi-dimensional effects of dance for people with Parkinson's disease. Contemp. Clin. Trials. https://doi.org/10.1016/j.cct.2016.10.001

Volpe, Daniele, Signorini, M., Marchetto, A., Lynch, T., Morris, M.E., 2013. A comparison of Irish set dancing and exercises for people with Parkinson's disease: A phase II feasibility study. BMC Geriatr. https://doi.org/10.1186/1471-2318-13-54

Volpe, D, Zanin, A., Clifford, A., Shahannan, J., Morris, M.E., 2013. A randomized controlled feasibility trial to determine the effectiveness of Irish set dancing for people with Parkinson's disease. Mov. Disord.

Wesch, N.N., Milne, M.I., Burke, S.M., Hall, C.R., 2006. Self-efficacy and imagery use in older adult exercisers. Eur. J. Sport Sci. https://doi.org/10.1080/17461390601012512

Westbrook, B.K., McKibben, H., 1989. Dance/movement therapy with groups of outpatients with Parkinson's disease. Am. J. Danc. Ther. https://doi.org/10.1007/BF00844264

Westheimer, O., 2008. Why Dance for Parkinson 's Disease 24, 127-140.

Westheimer, O., McRae, C., Henchcliffe, C., Fesharaki, A., Glazman, S., Ene, H., Bodis-Wollner, I., 
2015. Dance for PD: a preliminary investigation of effects on motor function and quality of life among persons with Parkinson's disease (PD). J. Neural Transm. https://doi.org/10.1007/s00702-015-1380-x

Wootton, A., Starkey, N.J., Barber, C.C., 2018. Unmoving and unmoved: experiences and consequences of impaired non-verbal expressivity in Parkinson's patients and their spouses. Disabil. Rehabil. https://doi.org/10.1080/09638288.2018.1471166

Wylie, S.A., Claassen, D.O., Huizenga, H.M., Schewel, K.D., Ridderinkhof, K.R., Bashore, T.R., van den Wildenberg, W.P.M., 2012. Dopamine Agonists and the Suppression of Impulsive Motor Actions in Parkinson Disease. J. Cogn. Neurosci. 24, 1709-1724.

Young, W.R., Rodger, M.W.M., Craig, C.M., 2014. Auditory observation of stepping actions can cue both spatial and temporal components of gait in Parkinson's disease patients. Neuropsychologia. https://doi.org/10.1016/j.neuropsychologia.2014.03.009

Zafar, M., Bozzorg, A., Hackney, M.E., 2017. Adapted Tango improves aspects of participation in older adults versus individuals with Parkinson's disease. Disabil. Rehabil. https://doi.org/10.1080/09638288.2016.1226405

Zatorre, R.J., Chen, J.L., Penhune, V.B., 2007. When the brain plays music: Auditory-motor interactions in music perception and production. Nat. Rev. Neurosci. https://doi.org/10.1038/nrn2152 
Table 1. Outcomes of dance in people with PD: Studies showing positive and null/negative effects in each domain (authors, year, dance style, study design/comparison group(s); ${ }^{*}$ indicates randomised controlled trial). Further details for each study are included in the supplementary material.

Domain; Studies reporting positive effects $\quad$ Studies reporting null/negative effects
outcome
measure

Motor severity

Unified

Parkinson's

Disease Rating

Scale (UPDRS) III
Allen et al. (2017): Tango; uncontrolled

Duncan \& Earhart (2012)*: Tango vs. nointervention

Duncan \& Earhart (2014)*: Tango vs. nointervention

Hackney \& Earhart (2009a): Tango; uncontrolled Heiberger et al. (2011): Mixed; uncontrolled Marchant et al. (2010): Modern (contact improvisation); uncontrolled

McKay et al. (2016): Tango; uncontrolled

McKee \& Hackney (2013)*: Tango vs. education

McNeely et al. (2015): Tango

McNeely et al. (2015): Mixed (Dance for PD)

Rabinovich et al. (2017): Tango; uncontrolled

Shanahan et al. (2015): Irish set; uncontrolled

Volpe et al. (2013)* : Irish set vs. individual physiotherapy

Westheimer et al. (2015): Mixed (Dance for PD); uncontrolled

\section{Balance}

Berg Balance Scale
Allen et al. (2017): Tango; uncontrolled

Bearss et al. (2017): Mixed (Dance for PD)

Hackney et al. (2007a)*: Tango vs.

strength/flexibility training

Hackney \& Earhart (2009b)*: Tango vs. nointervention

Hackney \& Earhart (2009b)*: Waltz/Foxtrot vs. no-intervention

Hackney \& Earhart (2010)*: Tango partnered and unpartnered

Hashimoto et al. (2015): Modern vs. exercise vs. no-intervention

Marchant et al. (2010): Modern (contact improvisation); uncontrolled

McKay et al. (2016): Tango; uncontrolled

Volpe et al. (2013)*: Irish set vs. individual physiotherapy
Hackney et al. (2007a)*: Tango vs.

strength/flexibility training

Hackney \& Earhart (2009a): Tango;

uncontrolled

Hackney \& Earhart (2009b)*: Tango vs. nointervention

Hackney \& Earhart (2009b)*: Waltz/Foxtrot vs. no-intervention

Hashimoto et al. (2015): Modern vs. exercise vs. no-intervention

Rawson et al. (2019): Tango vs. treadmill training vs. stretching

Rios Romenets et al. (2015)*: Tango vs. selfdirected exercise

Shanahan et al. (2017)*: Irish set vs. nointervention

De Natale et al. (2017)*: Tango vs. traditional rehabilitation

Shanahan et al. (2015): Irish set; uncontrolled

Westheimer et al. (2015): Mixed (Dance for PD); uncontrolled 
Mini-BESTest

Duncan \& Earhart (2012)*: Tango vs. nointervention

Duncan \& Earhart (2014)*: Tango vs. nointervention

McNeely et al. (2015): Mixed (Dance for PD)

McNeely et al. (2015): Tango

Rios Romenets et al. (2015)*: Tango vs. selfdirected exercise

Fullerton

Advanced

Balance scale

Activities-

Specific Balance

Confidence

Scale

Four Square

Step Test

Functional

Reach Test

Single-Leg

Stance Test

Semi-Tandem

Test

Standing

balance

Functional

mobility

Timed Up and Go
Allen et al. (2017): Tango; uncontrolled

Batson (2010): Modern (improvisational); uncontrolled

Batson et al. (2014): Modern (improvisational); uncontrolled

Houston \& McGill (2013): Ballet; uncontrolled

McKay et al. (2016): Tango; uncontrolled

McKee \& Hackney (2013)*: Tango vs. education

Hackney et al. (2007b)*: Tango vs.

strength/flexibility training

McNeely et al. (2015): Mixed (Dance for PD)

McNeely et al. (2015): Tango

Hackney \& Earhart (2010)*: Tango partnered and unpartnered

Bearss et al. (2017): Mixed (Dance for PD)

McNeely et al. (2015): Tango

De Natale et al. (2017)*: Tango vs. traditional rehabilitation

Rios Romenets et al. (2015)*: Tango vs. selfdirected exercise
Rawson et al. (2019): Tango vs. treadmill training vs. stretching

Shanahan et al. (2017)*: Irish set vs. nointervention

De Natale et al. (2017)*: Tango vs. traditional rehabilitation

McKee \& Hackney (2013)*: Tango vs. education

Hackney et al. (2007b)*: Tango vs. strength/flexibility training

McKay et al. (2016): Tango; uncontrolled

Hackney et al. (2007b)*: Tango vs. strength/flexibility training

Heiberger et al. (2011): Mixed; uncontrolled

Ventura et al. (2016)*: Mixed (Dance for PD) vs. no-intervention

Allen et al. (2017): Tango; uncontrolled

Batson (2010): Modern (improvisational); uncontrolled

Batson et al. (2014): Modern (improvisational); uncontrolled

Duncan \& Earhart (2014)*: Tango vs. no- 
Volpe et al. (2013)*: Irish set vs. individual physiotherapy
Timed Up and Go Dual-Task

6 Minute Walk Test

Duncan \& Earhart (2014)*: Tango vs. nointervention

Rios Romenets et al. (2015)*: Tango vs. selfdirected exercise

Allen et al. (2017): Tango; uncontrolled

Hackney \& Earhart (2009b)*: Tango vs. nointervention

Hackney \& Earhart (2009b)*: Waltz/Foxtrot vs. no-intervention

McNeely et al. (2015): Tango

McNeely et al. (2015): Mixed (Dance for PD)

De Natale et al. (2017)*: Tango vs. traditional rehabilitation

5 Times Sit-toStand Test intervention

Hackney et al. (2007a)*: Tango vs. strength/flexibility training

Hackney \& Earhart (2009a): Tango; uncontrolled

Hackney \& Earhart (2009b)*: Tango vs. nointervention

Hackney \& Earhart (2009b)*: Waltz/Foxtrot vs. no-intervention

Hackney \& Earhart (2010)*: Tango partnered and unpartnered

Hashimoto et al. (2015): Modern vs. exercise vs. no-intervention

Heiberger et al. (2011): Mixed; uncontrolled

Marchant et al. (2010): Modern (contact improvisation); uncontrolled

McKay et al. (2016): Tango; uncontrolled

McKee \& Hackney (2013)*: Tango vs.

education

McNeely et al. (2015): Mixed (Dance for PD)

Ventura et al. (2016)*: Mixed (Dance for PD) vs. no-intervention

Batson et al. (2014): Modern (improvisational); uncontrolled

McKay et al. (2016): Tango; uncontrolled

McKee \& Hackney (2013)*: Tango vs. education

Duncan \& Earhart (2012)*: Tango vs. nointervention

Duncan \& Earhart (2014)*: Tango vs. nointervention

Hackney \& Earhart (2009a): Tango; uncontrolled

Hackney \& Earhart (2010)*: Tango partnered and unpartnered

Marchant et al. (2010): Modern (contact improvisation); uncontrolled

McKay et al. (2016): Tango; uncontrolled

Rawson et al. (2019): Tango vs. treadmill training vs. stretching

Shanahan et al. (2015): Irish set; uncontrolled

Shanahan et al. (2017)*: Irish set vs. nointervention

Marchant et al. (2010): Modern (contact improvisation); uncontrolled 
Gait

Velocity

Other gait characteristics (e.g., cadence, stride length)

Dynamic Gait Index

Freezing of gait

FoG-Q
Duncan \& Earhart (2012)*: Tango vs. nointervention

Hackney \& Earhart (2010) ${ }^{*}$ : Tango partnered and unpartnered

Ventura et al. (2016)*: Mixed (Dance for PD) vs.

Westbrook \& McKibben (1989): DMT vs. exercise (cross-over) no-intervention

Allen et al. (2017): Tango; uncontrolled

Duncan \& Earhart (2012)* : Tango vs. nointervention

Duncan \& Earhart (2014)* : Tango vs. nointervention

Hackney et al. (2007b)* : Tango vs.

strength/flexibility training

Hackney \& Earhart (2009a): Tango; uncontrolled

Marchant et al. (2010): Modern (contact improvisation); uncontrolled

McNeely et al. (2015): Tango

McNeely et al. (2015): Mixed (Dance for PD)

Rawson et al. (2019): Tango vs. treadmill training vs. stretching

Hackney \& Earhart (2009a): Tango; uncontrolled

Marchant et al. (2010): Modern (contact improvisation); uncontrolled

Rawson et al. (2019): Tango vs. treadmill training vs. stretching

improvisation); uncontrolled

Allen et al. (2017): Tango; uncontrolled

McKay et al. (2016): Tango; uncontrolled

De Natale et al. (2017)*: Tango vs. traditional rehabilitation

Duncan \& Earhart (2012)*: Tango vs. nointervention

Duncan \& Earhart (2014)* : Tango vs. nointervention

Hackney et al. (2007a)*: Tango vs. strength/flexibility training

Hackney \& Earhart (2009b)* : Tango vs. nointervention

Hackney \& Earhart (2009b)*: Waltz/Foxtrot vs. no-intervention

Marchant et al. (2010): Modern (contact improvisation); uncontrolled

McKay et al. (2016): Tango; uncontrolled

McKee \& Hackney (2013)*: Tango vs.

education 
Dexterity

9 Hole Peg Test

Duncan \& Earhart (2012) ${ }^{*}$ : Tango vs. nointervention

Activities of

Daily Living

UPDRS-II

Duncan \& Earhart (2014)*: Tango vs. nointervention

Duncan \& Earhart (2012)*: Tango vs. nointervention

Falls

Falls Efficacy

Ventura et al. (2016)*: Mixed (Dance for PD) vs. no-intervention

Hackney et al. (2007b)*: Tango vs.

Scale

Non-motor

symptoms of PD

UPDRS-I

Duncan \& Earhart (2014)*: Tango vs. nointervention

Duncan \& Earhart (2012)*: Tango vs. nointervention

Fatigue Scale

Rios Romenets et al. (2015)*: Tango vs. selfdirected exercise

Quality of life

Parkinson's

Disease

Questionnaire

(PDQ-39)

Oregon Quality of Life

Questionnaire

EuroQol-5D

Short Form

Health Survey

SF-12
Hackney \& Earhart (2009c)*: Tango vs. Waltz/Foxtrot vs. Tai Chi vs. no-intervention

Shanahan et al. (2015): Irish set; uncontrolled

Hackney \& Earhart (2009c)* : Waltz/Foxtrot vs. Tango vs. Tai Chi vs. no-intervention

McKee \& Hackney (2013)*: Tango vs. education

McNeely et al. (2015): Tango

McNeely et al. (2015): Mixed (Dance for PD)

Rawson et al. (2019): Tango vs. treadmill training vs. stretching

Shanahan et al. (2017)* : Irish set vs. nointervention

Ventura et al. (2016)*: Mixed (Dance for PD) vs. no-intervention

Volpe et al. (2013)*: Irish set vs. individual physiotherapy

Wesheimer et al. (2015): Mixed (Dance for PD); uncontrolled

Heiberger et al. (2011): Mixed; uncontrolled Westheimer (2008): Mixed (Dance for PD)
Bearss et al. (2017): Mixed (Dance for PD); uncontrolled

Blandy et al. (2015): Tango; uncontrolled

McKee \& Hackney (2013)*: Tango vs.

education 
Activities Card

Sort

Cognition

\begin{tabular}{|c|c|}
\hline Montreal & McKee \& Hackney $(2013)^{*}$ : Tango vs. education \\
\hline $\begin{array}{l}\text { Cognitive } \\
\text { Assessment } \\
\text { (MoCA) }\end{array}$ & $\begin{array}{l}\text { Rios Romenets et al. (2015)*: Tango vs. self- } \\
\text { directed exercise }\end{array}$ \\
\hline $\begin{array}{l}\text { Test of Everyday } \\
\text { Attention }\end{array}$ & $\begin{array}{l}\text { Ventura et al. (2016)*: Mixed (Dance for PD) vs. } \\
\text { no-intervention }\end{array}$ \\
\hline Mental Rotation & $\begin{array}{l}\text { Hashimoto et al. (2015): Modern vs. no- } \\
\text { intervention }\end{array}$ \\
\hline $\begin{array}{l}\text { Trail Making } \\
\text { Test }\end{array}$ & $\begin{array}{l}\text { De Natale et al. (2017) }{ }^{*} \text { : Tango vs. traditional } \\
\text { rehabilitation }\end{array}$ \\
\hline $\begin{array}{l}\text { Brooks Spatial } \\
\text { Test }\end{array}$ & McKee \& Hackney (2013)*: Tango vs. education \\
\hline $\begin{array}{l}\text { Digit span } \\
\text { forward }\end{array}$ & $\begin{array}{l}\text { Ventura et al. (2016)*: Mixed (Dance for PD) vs. } \\
\text { no-intervention }\end{array}$ \\
\hline
\end{tabular}

Digit span

backward

Frontal

Assessment

Battery

Verbal fluency

(category/

action)

Reverse Corsi

Blocks

Stroop Task

Mood/Affect

Beck Depression Blandy et al. (2015): Tango; uncontrolled Inventory

Foster et al. (2013)*: Tango vs. no-intervention no-intervention

Hashimoto et al. (2015): Modern vs. nointervention 
Profile of Mood Lewis et al. (2016): Mixed; uncontrolled

States

Brunel

University Mood

Scale

Apathy Scale

Hashimoto et al. (2015): Modern vs. exercise vs. no-intervention

Philadelphia

Geriatric Morale

Scale
Lewis et al. (2016): Mixed; uncontrolled

Rios Romenets et al. (2015)*: Tango vs. selfdirected exercise

Hackney et al. (2007b)*: Tango vs.

strength/flexibility training

Notes: Hackney \& Earhart (2010) effects apply to both partnered and unpartnered Tango groups. Hashimoto et al. (2015) both dance and exercise group improved on Frontal Assessment Battery and Mental Rotation compared with the control group. 
Table S1. Sensorimotor outcomes of dance reported in people with PD

\begin{tabular}{|c|c|c|c|c|c|c|c|}
\hline Article & $\begin{array}{l}\text { Dance } \\
\text { intervention: } \\
\text { duration, } \\
\text { frequency }\end{array}$ & $\begin{array}{l}\text { Study design; } \\
\text { control/ } \\
\text { comparison } \\
\text { group(s) }\end{array}$ & $\begin{array}{l}\text { References to } \\
\text { action } \\
\text { representation }\end{array}$ & $\begin{array}{l}\text { Participants per } \\
\text { group (n female); } \\
\text { age; Hoehn \& Yahr } \\
\text { stage (H\&Y); time } \\
\text { since diagnosis. }^{2}\end{array}$ & $\begin{array}{l}\text { Outcome measures; } \\
\text { medication status at } \\
\text { assessment (meds) }\end{array}$ & Follow-up & Results \\
\hline $\begin{array}{l}\text { Allen et al. } \\
\text { (2017) }\end{array}$ & $\begin{array}{l}\text { Tango: } 3 \text { weeks, } 5 \\
\text { x } 90 \text { minutes. }\end{array}$ & $\begin{array}{l}\text { Uncontrolled } \\
\text { N/A }\end{array}$ & & $\begin{array}{l}6(1 f) ; \text { age } 64.0 \\
\text { years; H\&Y } 2-3 \\
\text { duration } 7.0 \text { years. }\end{array}$ & $\begin{array}{l}\text { UPDRS-III; TUG; BBS; } \\
\text { FAB; DGI; 6MWT; Gait } \\
\text { velocity } \\
\text { (preferred,fast). }\end{array}$ & N/A & $\begin{array}{l}\text { Medium to large effect sizes for } \\
\text { UPDRS-III, (0.55), BBS (1.17); FAB } \\
\text { (0.83); DGI (0.87); 6MWT (0.79); } \\
\text { small effect for TUG (0.46). }\end{array}$ \\
\hline $\begin{array}{l}\text { Batson } \\
(2010)\end{array}$ & $\begin{array}{l}\text { Modern } \\
\text { (improvisational): } \\
3 \text { weeks, } 85 \\
\text { minutes }\end{array}$ & $\begin{array}{l}\text { Uncontrolled } \\
\text { N/A }\end{array}$ & Motor imagery & $\begin{array}{l}11(6 f) ; \text { age } 72.7 \\
\text { years; H\&Y } 1-2.5 \\
\text { duration } 1-6 \text { years. }\end{array}$ & $\begin{array}{l}\text { TUG; FAB } \\
\text { Meds: on }\end{array}$ & $N / A$ & Improvement on FAB $(p<.01)$ \\
\hline $\begin{array}{l}\text { Batson et al. } \\
(2014)\end{array}$ & $\begin{array}{l}\text { Modern } \\
\text { (improvisational): } \\
7 \text { weeks, } 3 \times 60 \\
\text { minutes. Followed } \\
\text { by single case } \\
\text { study - } 5 \\
\text { consecutive days, } \\
60 \text { minutes. }\end{array}$ & $\begin{array}{l}\text { Uncontrolled } \\
\text { two-phase } \\
\text { study (group/ } \\
\text { individual case) } \\
\text { N/A }\end{array}$ & Imaging & $\begin{array}{l}7(5 f) ; \text { age } 67 \text { years; } \\
\text { H\&Y } 2.5 \text { (mode); } \\
\text { duration NR. }\end{array}$ & $\begin{array}{l}\text { TUG; TUG-DT; FAB } \\
\text { Meds: NR }\end{array}$ & N/A & $\begin{array}{l}\text { Group improvement on FAB }(p=.02) \text {. } \\
\text { Case study showed increased } \\
\text { functional connectivity. }\end{array}$ \\
\hline $\begin{array}{l}\text { Bearss et al. } \\
(2017)\end{array}$ & $\begin{array}{l}\text { Dance for PD: } 12 \\
\text { weeks (outcomes } \\
\text { tested at weeks } 2 \\
\text { and 12), } 75 \\
\text { minutes }\end{array}$ & $\begin{array}{l}\text { Uncontrolled } \\
\text { N/A }\end{array}$ & Imagery; mirroring & $\begin{array}{l}9(4 \mathrm{f}) ; \text { age } 67.8 \\
\text { years; } \mathrm{H} \& \mathrm{Y} 0.8 ; \\
\text { duration } 5.6 \text { years. }\end{array}$ & $\begin{array}{l}\text { TUG; BBS } \\
\text { Meds: NR }\end{array}$ & $N / A$ & $\begin{array}{l}\text { Improvements on BBS }(p=.02) \text { and } \\
\text { TUG }(p=.04)\end{array}$ \\
\hline $\begin{array}{l}\text { Delextrat et } \\
\text { al. (2016) }\end{array}$ & $\begin{array}{l}\text { Zumba Gold: } 6 \\
\text { weeks, } 45-60 \\
\text { minutes } \\
\text { (increasing with } \\
\text { class progression) }\end{array}$ & $\begin{array}{l}\text { Uncontrolled } \\
\text { feasibility } \\
\text { N/A }\end{array}$ & & $\begin{array}{l}11(6 f) ; \text { age } 64 \text { years; } \\
\text { H\&Y } 1.5(M d n) ; \\
\text { duration NR. }\end{array}$ & $\begin{array}{l}\text { Physical activity } \\
\text { (triaxial } \\
\text { accelerometers); } \\
\text { physiological load } \\
\text { (heart rate). }\end{array}$ & $\begin{array}{l}\text { Interview } 6 \\
\text { months } \\
\text { later }(n=8)\end{array}$ & $\begin{array}{l}\text { Improvement in activity levels } \\
(p=.02) \text { between first and last } \\
\text { session. }\end{array}$ \\
\hline & & & & & Meds: on & & \\
\hline
\end{tabular}




\begin{tabular}{|c|c|c|c|c|c|c|c|}
\hline Article & $\begin{array}{l}\text { Dance } \\
\text { intervention: } \\
\text { duration, } \\
\text { frequency }\end{array}$ & $\begin{array}{l}\text { Study design; } \\
\text { control/ } \\
\text { comparison } \\
\text { group }(s)^{1}\end{array}$ & $\begin{array}{l}\text { References to } \\
\text { action } \\
\text { representation }\end{array}$ & $\begin{array}{l}\text { Participants per } \\
\text { group (n female); } \\
\text { age; Hoehn \& Yahr } \\
\text { stage (H\&Y); time } \\
\text { since diagnosis. }^{2}\end{array}$ & $\begin{array}{l}\text { Outcome measures; } \\
\text { medication status at } \\
\text { assessment (meds) }\end{array}$ & Follow-up & Results \\
\hline $\begin{array}{l}\text { Duncan \& } \\
\text { Earhart } \\
(2012)\end{array}$ & $\begin{array}{l}\text { Tango; } 12 \text { months } \\
\text { (outcomes tested } \\
\text { at } 3,6 \text { and } 12 \\
\text { months), } 2 \times 60 \\
\text { minutes }\end{array}$ & $\begin{array}{l}\text { RCT } \\
\text { Control: no } \\
\text { intervention }\end{array}$ & & $\begin{array}{l}\text { Dance: } 26 \text { (11f); age } \\
69.3 \text { years; H\&Y 2.6; } \\
\text { duration } 5.8 \text { years. } \\
\text { Control: } 26 \text { (11f); } \\
\text { age } 69 \text { years; H\&Y } \\
\text { 2.5; duration } 7 \\
\text { years. }\end{array}$ & $\begin{array}{l}\text { MDS-UPDRS III and II; } \\
\text { Mini-BESTest; gait } \\
\text { velocity (forward- } \\
\text { comfortable, forward- } \\
\text { fast, dual-task, } \\
\text { backward); 6MWT; } \\
\text { FOGQ; nine-hole peg } \\
\text { test. } \\
\text { Meds: off }\end{array}$ & N/A & $\begin{array}{l}\text { Dance group improved vs. control } \\
\text { group on UPDRS-III and Mini-BESTest } \\
\text { ( } p<.001 \text { ) by } 3 \text { months, forward- } \\
\text { comfortable }(p=.04) \text { and dual-task } \\
\text { ( } p=.02 \text { ) gait velocity and nine-hole } \\
\text { peg test ( } p=.01 \text { ) by } 6 \text { months. } \\
\text { Controls deteriorated on FOGQ and } \\
\text { 6MWT by } 12 \text { months while dance } \\
\text { group showed no change. }\end{array}$ \\
\hline $\begin{array}{l}\text { Duncan \& } \\
\text { Earhart } \\
(2014)\end{array}$ & $\begin{array}{l}\text { Tango: } 2 \text { years, } 2 x \\
60 \text { minutes }\end{array}$ & $\begin{array}{l}\text { Pilot RCT } \\
\text { Control: no } \\
\text { intervention. }\end{array}$ & & $\begin{array}{l}\text { Dance: } 5 \text { (1f); age } \\
69.6 \text { years; H\&Y } 2 \text { - } \\
\text { 3; duration } 6.6 \\
\text { years. } \\
\text { Control: } 5 \text { (1f); age } \\
66 \text { years; H\&Y 2- } 2.5 \text {; } \\
\text { duration } 11 \text { years. }\end{array}$ & $\begin{array}{l}\text { MDS-UPDRS III and II; } \\
\text { Mini-BESTest; gait } \\
\text { velocity (forward and } \\
\text { backward); TUG; TUG- } \\
\text { DT; 6MWT; FOGQ. } \\
\text { Meds: off }\end{array}$ & N/A & $\begin{array}{l}\text { Dance group improved vs. control } \\
\text { group on UPDRS-III }(p<.001) \text { Mini- } \\
\text { BESTest ( } p<.001) \text { at } 12 \text { and } 24 \\
\text { months, and UPDRS-II ( } p=.05 \text { ) at } 24 \\
\text { months. Across the duration of the } \\
\text { study dance group improved on } \\
\text { TUG-DT but controls worsened } \\
\text { ( } p<.05) \text {; dance group showed no } \\
\text { change on 6MWT while controls } \\
\text { worsened on }(p=.01) \text {. }\end{array}$ \\
\hline $\begin{array}{l}\text { Hackney et } \\
\text { al. (2007a) }\end{array}$ & $\begin{array}{l}\text { Tango: } 13 \text { weeks } \\
\text { (10 weeks of } \\
\text { classes), } 2 \text { × } 60 \\
\text { minutes }\end{array}$ & $\begin{array}{l}\text { RCT } \\
\text { Exercise: } \\
\text { structured } \\
\text { strength/ } \\
\text { flexibility } \\
\text { training }\end{array}$ & Imagery & $\begin{array}{l}\text { Dance: } 9(3 \mathrm{f}) \text {; age } \\
72.6 \text { years; } \mathrm{H} \& \mathrm{Y} 2.3 \text {; } \\
\text { duration } 6.2 \text { years. } \\
\text { Exercise: } 10 \text { (4f); age } \\
69.6 \text { years; } 2.2 \text {; } \\
\text { duration } 3.3 \text { years. }\end{array}$ & $\begin{array}{l}\text { UPDRS-III; BBS; TUG; } \\
\text { FOGQ. } \\
\text { Meds: on }\end{array}$ & $\mathrm{N} / \mathrm{A}$ & $\begin{array}{l}\text { Both groups improved on UPDRS-III } \\
(p<.001) \text {. Dance group improved on } \\
\text { BBS }(p=.01)\end{array}$ \\
\hline
\end{tabular}




\begin{tabular}{|c|c|c|c|c|c|c|c|}
\hline Article & $\begin{array}{l}\text { Dance } \\
\text { intervention: } \\
\text { duration, } \\
\text { frequency }\end{array}$ & $\begin{array}{l}\text { Study design; } \\
\text { control/ } \\
\text { comparison } \\
\text { group(s) }\end{array}$ & $\begin{array}{l}\text { References to } \\
\text { action } \\
\text { representation }\end{array}$ & $\begin{array}{l}\text { Participants per } \\
\text { group ( } \mathrm{n} \text { female); } \\
\text { age; Hoehn \& Yahr } \\
\text { stage (H\&Y); time } \\
\text { since diagnosis. }^{2}\end{array}$ & $\begin{array}{l}\text { Outcome measures; } \\
\text { medication status at } \\
\text { assessment (meds) }\end{array}$ & Follow-up & Results \\
\hline $\begin{array}{l}\text { Hackney et } \\
\text { al. (2007b) }\end{array}$ & $\begin{array}{l}\text { Tango: } 13 \text { weeks } \\
\text { (10 weeks of } \\
\text { classes), } 2 \text { x } 60 \\
\text { minutes }\end{array}$ & $\begin{array}{l}\text { RCT } \\
\text { Exercise: } \\
\text { structured } \\
\text { strength/ } \\
\text { flexibility } \\
\text { training }\end{array}$ & & $\begin{array}{l}\text { Dance: } 9 \text { (NR). } \\
\text { Exercise: } 10 \text { (NR). } \\
\text { Matched numbers of } \\
\text { healthy controls in } \\
\text { each group; all aged } \\
55+\text { years. Disease } \\
\text { stage and duration } \\
\text { NR. }\end{array}$ & $\begin{array}{l}\text { ABC Scale; Modified } \\
\text { Falls Efficacy Scale; } \\
\text { Functional Reach } \\
\text { Test; One Leg Stance } \\
\text { Test; gait velocity } \\
\text { (motion capture). } \\
\text { Meds: NR }\end{array}$ & $\mathrm{N} / \mathrm{A}$ & $\begin{array}{l}\text { PD Tango group improved vs. PD } \\
\text { exercise group on } A B C \text { scale. Healthy } \\
\text { controls showed the reverse pattern. }\end{array}$ \\
\hline $\begin{array}{l}\text { Hackney \& } \\
\text { Earhart } \\
\text { (2009a) }\end{array}$ & $\begin{array}{l}\text { Tango; } 2 \text { weeks, } 5 \\
\text { x } 90 \text { minutes }\end{array}$ & $\begin{array}{l}\text { Uncontrolled } \\
\text { N/A }\end{array}$ & & $\begin{array}{l}12(4 f) ; \text { age } 67.2 \\
\text { years; H\&Y } 2.4 \\
\text { (Mdn); duration } 9.1 \\
\text { years. }\end{array}$ & $\begin{array}{l}\text { UPDRS-III; BBS; TUG; } \\
\text { 6MWT; gait analysis } \\
\text { (preferred; forward } \\
\text { and backward) using } \\
\text { instrumented } \\
\text { walkway. } \\
\text { Meds: on }\end{array}$ & $\mathrm{N} / \mathrm{A}$ & $\begin{array}{l}\text { Improvements on UPDRS-III }(p=.03) \text {, } \\
\text { BBS }(p=.02) \text {, percent stance time } \\
\text { during forward walking }(p=.02) \text {. }\end{array}$ \\
\hline $\begin{array}{l}\text { Hackney \& } \\
\text { Earhart } \\
\text { (2009b) }\end{array}$ & $\begin{array}{l}\text { Tango, Waltz/ } \\
\text { Foxtrot: } 13 \text { weeks } \\
\text { (10 weeks of } \\
\text { classes), } 2 \text { × } 60 \\
\text { minutes }\end{array}$ & $\begin{array}{l}\text { RCT } \\
\text { Control: no } \\
\text { intervention. }\end{array}$ & & $\begin{array}{l}\text { Tango: } 14 \text { (3f); age } \\
68.2 \text { years; H\&Y } 2.1 ; \\
\text { duration } 6.9 \text { years. } \\
\text { Waltz/Foxtrot: } 17 \\
\text { (6f); age } 66.8 \text { years; } \\
\text { H\&Y 2.0; duration } \\
9.2 \text { years. } \\
\text { Control: } 17 \text { (5f); age } \\
66.5 \text { years; H\&Y } 2.2 \text {; } \\
\text { duration } 5.9 \text { years. }\end{array}$ & $\begin{array}{l}\text { UPDRS-III; BBS; TUG; } \\
\text { 6MWT; FOGQ. } \\
\text { Meds: on }\end{array}$ & $\mathrm{N} / \mathrm{A}$ & $\begin{array}{l}\text { Both dance groups improved on BBS } \\
\text { (Waltz/Foxtrot } p<.001 ; \text { Tango } p \\
=.001 \text { ) and 6MWT (both } p<.001) \text {. } \\
\text { Control group worsened on UPDRS- } \\
\text { III }(p=.002) .\end{array}$ \\
\hline
\end{tabular}




\begin{tabular}{|c|c|c|c|c|c|c|c|}
\hline Article & $\begin{array}{l}\text { Dance } \\
\text { intervention: } \\
\text { duration, } \\
\text { frequency }\end{array}$ & $\begin{array}{l}\text { Study design; } \\
\text { control/ } \\
\text { comparison } \\
\text { group(s) }\end{array}$ & $\begin{array}{l}\text { References to } \\
\text { action } \\
\text { representation }\end{array}$ & $\begin{array}{l}\text { Participants per } \\
\text { group (n female); } \\
\text { age; Hoehn \& Yahr } \\
\text { stage (H\&Y); time } \\
\text { since diagnosis. }{ }^{2}\end{array}$ & $\begin{array}{l}\text { Outcome measures; } \\
\text { medication status at } \\
\text { assessment (meds) }\end{array}$ & Follow-up & Results \\
\hline $\begin{array}{l}\text { Hackney \& } \\
\text { Earhart } \\
(2010)\end{array}$ & $\begin{array}{l}\text { Partnered Tango, } \\
\text { Unpartnered } \\
\text { Tango: } 10 \text { weeks, } 2 \\
\text { x } 60 \text { minutes }\end{array}$ & $\begin{array}{l}\text { RCT } \\
\text { N/A }\end{array}$ & & $\begin{array}{l}\text { Partnered: } 19 \text { (6f); } \\
\text { age } 69.6 \text { years; H\&Y } \\
2.5 \text { (Mdn); duration } \\
9.5 \text { years. } \\
\text { Non-partnered: } 20 \\
\text { (5f); age } 69.6 \text { years; } \\
\text { H\&Y } 2 \text { (Mdn); } \\
\text { duration } 7.9 \text { years. }\end{array}$ & $\begin{array}{l}\text { BBS; tandem stance; } \\
\text { single-leg stance; TUG; } \\
\text { 6MWT; gait analysis } \\
\text { (preferred, fast) using } \\
\text { GAITrite walkway. } \\
\text { Meds: on }\end{array}$ & 4 weeks & $\begin{array}{l}\text { Both groups improved on BBS, } \\
\text { preferred and fast walking velocity } \\
\text { and cadence, fast swing percent and } \\
\text { double support percent, single-leg } \\
\text { and tandem stance time. All except } \\
\text { single-leg stance time maintained at } \\
\text { one-month follow-up. }\end{array}$ \\
\hline $\begin{array}{l}\text { Hashimoto } \\
\text { et al. (2015) }\end{array}$ & $\begin{array}{l}\text { Modern dance: } 12 \\
\text { weeks, } 60 \\
\text { minutes. }\end{array}$ & $\begin{array}{l}\text { Quasi-RCT } \\
\text { Exercise: } \\
\text { physical } \\
\text { therapy and } \\
\text { PD-specific } \\
\text { exercises. } \\
\text { Control: no } \\
\text { intervention. }\end{array}$ & Visualisation & $\begin{array}{l}\text { Dance: } 15 \text { (12f); age } \\
67.9 \text { years; H\&Y } 2.7 \text {; } \\
\text { duration } 6.3 \text { years. } \\
\text { Exercise: } 17 \text { (15f); } \\
\text { age } 62.7 \text { years; H\&Y } \\
\text { 2.7; duration } 7.8 \\
\text { years. } \\
\text { Control: } 14 \text { (7f); age } \\
69.7 \text { years; H\&Y 3.0; } \\
\text { duration } 6.9 \text { years. }\end{array}$ & $\begin{array}{l}\text { UPDRS-III; TUG; TUG } \\
\text { step count; BBS. } \\
\text { Meds: on }\end{array}$ & $\mathrm{N} / \mathrm{A}$ & $\begin{array}{l}\text { All groups improved on TUG time } \\
\text { (dance } p=.006 \text {; exercise } p=.04 ; \\
\text { control } p=.03 \text { ). Dance and exercise } \\
\text { groups improved on TUG step count } \\
\text { (dance } p<.01 \text {; exercise } p=.01 \text { ). } \\
\text { Dance group improved on BBS ( } p \\
=.001 \text { ). }\end{array}$ \\
\hline $\begin{array}{l}\text { Heiberger et } \\
\text { al. (2011) }\end{array}$ & $\begin{array}{l}\text { Mixed style: } 8 \\
\text { months, } 75 \\
\text { minutes. } \\
\text { (outcomes tested } \\
\text { pre/post a single } \\
\text { class in ongoing } \\
\text { participants. }\end{array}$ & $\begin{array}{l}\text { Uncontrolled } \\
\text { N/A }\end{array}$ & Motor imagery & $\begin{array}{l}11(6 f) ; \text { age } 71.3 \\
\text { years; H\&Y 3.3; } \\
\text { duration NR. }\end{array}$ & $\begin{array}{l}\text { UPDRS-III; TUG; Semi- } \\
\text { tandem test. } \\
\text { Meds: off }\end{array}$ & N/A & Improvement in UPDRS-III $(p=.001)$. \\
\hline $\begin{array}{l}\text { Houston \& } \\
\text { McGill } \\
(2013)\end{array}$ & $\begin{array}{l}\text { Adapted ballet: } 16 \\
\text { weeks ( } 12 \text { weeks } \\
\text { of classes), } 90 \\
\text { minutes. }\end{array}$ & $\begin{array}{l}\text { Uncontrolled/ } \\
\text { mixed- } \\
\text { methods } \\
\text { N/A }\end{array}$ & $\begin{array}{l}\text { Imagery } \\
\text { (kinaesthetic, } \\
\text { visual and musical) }\end{array}$ & $\begin{array}{l}\text { Participants } \\
\text { completing } \\
\text { quantitative } \\
\text { assessments: } 6 \text { ( } 3 f) ; \\
\text { age } 70.0 \text { years; H\&Y } \\
\text { 1-4 (estimated); } \\
\text { duration NR. }\end{array}$ & $\begin{array}{l}\text { FAB; plumb-line } \\
\text { assessment; } \\
\text { qualitative analysis of } \\
\text { movement from video } \\
\text { recordings. } \\
\text { Meds: on }\end{array}$ & N/A & $\begin{array}{l}\text { Improvement on FAB }(p=.01) \text {. } \\
\text { Qualitative improvements in } \\
\text { movement noted from video } \\
\text { analysis. }\end{array}$ \\
\hline
\end{tabular}




\begin{tabular}{|c|c|c|c|c|c|c|c|}
\hline Article & $\begin{array}{l}\text { Dance } \\
\text { intervention: } \\
\text { duration, } \\
\text { frequency }\end{array}$ & $\begin{array}{l}\text { Study design; } \\
\text { control/ } \\
\text { comparison } \\
\text { group(s) }\end{array}$ & $\begin{array}{l}\text { References to } \\
\text { action } \\
\text { representation }\end{array}$ & $\begin{array}{l}\text { Participants per } \\
\text { group (n female); } \\
\text { age; Hoehn \& Yahr } \\
\text { stage (H\&Y); time } \\
\text { since diagnosis. }^{2}\end{array}$ & $\begin{array}{l}\text { Outcome measures; } \\
\text { medication status at } \\
\text { assessment (meds) }\end{array}$ & Follow-up & Results \\
\hline $\begin{array}{l}\text { Marchant et } \\
\text { al. (2010) }\end{array}$ & $\begin{array}{l}\text { Modern (contact } \\
\text { improvisation): } 2 \\
\text { weeks, } 5 \text { × } 90 \\
\text { minutes. }\end{array}$ & $\begin{array}{l}\text { Uncontrolled } \\
\text { pilot study } \\
\text { N/A }\end{array}$ & & $\begin{array}{l}11(7 f) ; \text { age } 71.2 \\
\text { years; H\&Y } 2.4 ; \\
\text { duration } 9.0 \text { years. }\end{array}$ & $\begin{array}{l}\text { UPDRS-III; BBS; TUG; } \\
\text { 6MWT; } 5 \text { times sit-to- } \\
\text { stand test; gait } \\
\text { analysis (preferred- } \\
\text { forward; fast-forward; } \\
\text { preferred-backward) } \\
\text { using GAITRite } \\
\text { walkway; FOGQ. } \\
\text { Meds: on }\end{array}$ & N/A & $\begin{array}{l}\text { Improvements on UPDRS-III, BBS, } \\
\text { percentage of cycle in stance and } \\
\text { swing during forward preferred } \\
\text { speed gait (all } p \leq .02 \text { ). }\end{array}$ \\
\hline $\begin{array}{l}\text { McKay et al. } \\
(2016)\end{array}$ & $\begin{array}{l}\text { Tango: } 3 \text { weeks, } 5 \\
\text { x } 90 \text { minutes. }\end{array}$ & $\begin{array}{l}\text { Uncontrolled } \\
\text { N/A }\end{array}$ & & $\begin{array}{l}22(15 f) ; \text { age } 65.4 \\
\text { years; H\&Y } 2 \text { - } 3 \text {; } \\
\text { duration } 3-14 \\
\text { years. }\end{array}$ & $\begin{array}{l}\text { UPDRS-III; BBS; TUG; } \\
\text { TUG-DT; ABC; FOGQ; } \\
\text { dyskinesia rating; DGI; } \\
\text { FAB; 6MWT; two- } \\
\text { footed jump test; } \\
\text { functional reach; gait } \\
\text { speed (preferred, fast) } \\
\text { using a stopwatch. } \\
\text { Subset ( } n=9 \text { ) } \\
\text { assessed for } \\
\text { perturbation response } \\
\text { pre/post intervention. } \\
\text { Meds: on }\end{array}$ & One month & $\begin{array}{l}\text { Improvements on BBS, }(p<0.01), F A B \\
(p<0.001) \text {, and DGI }(p=0.01) ; \\
\text { maintained at one-month follow-up. } \\
\text { CoM displacement during forward } \\
\text { perturbation reduced at post-test ( } p \\
=.03) \text {. Preferred }(p<.01) \text { and fast ( } p \\
=.03) \text { cadence and UPDRS-III } \\
(p<0.01) \text { improved from pre-test to } \\
\text { follow-up. Reductions in forward } \\
\text { CoM displacement correlated with } \\
\text { increased scores on BBS }(p=0.04) \text { and } \\
\text { DGI ( } p=0.03 \text { ). }\end{array}$ \\
\hline $\begin{array}{l}\text { McKee \& } \\
\text { Hackney } \\
\text { (2013) }\end{array}$ & $\begin{array}{l}\text { Tango: } 12 \text { weeks } \\
\text { (10 weeks of } \\
\text { classes), } 90 \\
\text { minutes. }\end{array}$ & $\begin{array}{l}\text { RCT } \\
\text { Educational } \\
\text { seminars: } \\
\text { lectures, } \\
\text { discussion and } \\
\text { structured } \\
\text { group learning } \\
\text { activities. }\end{array}$ & & $\begin{array}{l}\text { Dance: } 24 \text { (12f); age } \\
68.4 \text { years; H\&Y } 2.3 \\
\text { (Mdn); duration } 7.0 \\
\text { years. } \\
\text { Education: } 9 \text { (1f); } \\
\text { age } 74.4 \text { years; H\&Y } \\
2.0 \text { (Mdn); duration } \\
7.2 \text { years. }\end{array}$ & $\begin{array}{l}\text { UPDRS-III; FAB; TUG; } \\
\text { TUG-DT (cognitive and } \\
\text { manual tasks); 4SST; } \\
\text { FOGQ. } \\
\text { Meds: on }\end{array}$ & $\begin{array}{l}10-12 \\
\text { weeks }\end{array}$ & $\begin{array}{l}\text { Both groups improved on } 4 \text { SST ( } p \\
=.03 \text { ). Dance group improved on } \\
\text { UPDRS-III ( } p=.02) \text {, FAB ( } p=.004) \text {, } \\
\text { which were maintained at } 10-12 \\
\text { week follow-up. Education group } \\
\text { worsened on UPDRS-III ( } p=.04) \text {. }\end{array}$ \\
\hline
\end{tabular}




\begin{tabular}{|c|c|c|c|c|c|c|c|}
\hline Article & $\begin{array}{l}\text { Dance } \\
\text { intervention: } \\
\text { duration, } \\
\text { frequency }\end{array}$ & $\begin{array}{l}\text { Study design; } \\
\text { control/ } \\
\text { comparison } \\
\text { group(s) }\end{array}$ & $\begin{array}{l}\text { References to } \\
\text { action } \\
\text { representation }\end{array}$ & $\begin{array}{l}\text { Participants per } \\
\text { group (n female); } \\
\text { age; Hoehn \& Yahr } \\
\text { stage (H\&Y); time } \\
\text { since diagnosis. }{ }^{2}\end{array}$ & $\begin{array}{l}\text { Outcome measures; } \\
\text { medication status at } \\
\text { assessment (meds) }\end{array}$ & Follow-up & Results \\
\hline $\begin{array}{l}\text { McNeely et } \\
\text { al. (2015) }\end{array}$ & $\begin{array}{l}\text { Dance for PD, } \\
\text { Tango: } 12 \text { weeks, } 2 \\
\text { x } 60 \text { minutes. }\end{array}$ & $\begin{array}{l}\text { Between- } \\
\text { groups }\end{array}$ & $\begin{array}{l}\text { Dance for PD: } \\
\text { imagery; mirroring }\end{array}$ & $\begin{array}{l}\text { Dance for PD: } 8 \text { (4f); } \\
\text { age } 68.3 \text { years; H\&Y } \\
2.3 \text {; duration } 10.1 \\
\text { years. } \\
\text { Tango: } 8 \text { (4f); age } \\
67.7 \text { years; H\&Y } 2.1 \text {; } \\
\text { duration } 5.4 \text { years. }\end{array}$ & $\begin{array}{l}\text { UPDRS-III; Mini- } \\
\text { BESTest; 6MWT; } 5 \\
\text { times sit-to-stand; } \\
\text { 4SST; gait analysis } \\
\text { (comfortable-forward; } \\
\text { fast-forward; } \\
\text { backward; cognitive } \\
\text { dual-task) using } \\
\text { GAITRite walkway. } \\
\text { Meds: off }\end{array}$ & $\mathrm{N} / \mathrm{A}$ & $\begin{array}{l}\text { Both groups improved on UPDRS-III } \\
(p=.001) \text {, Mini-BESTest }(p=.04), 5 \\
\text { times sit-to-stand }(p=.004), 4 S S T \\
(P=.003), 6 M W T(p=.03) \text {. Tango } \\
\text { group showed greater improvement } \\
\text { in UPDRS-III (interaction } p=.01) ; \text { TUG } \\
\text { time improved in Tango group but } \\
\text { worsened in Dance for PD group } \\
\text { (interaction, } p=.04) \text {. }\end{array}$ \\
\hline $\begin{array}{l}\text { De Natale et } \\
\text { al. (2017) }\end{array}$ & $\begin{array}{l}\text { Tango: } 10 \text { weeks, } 2 \\
\text { x } 60 \text { minutes. }\end{array}$ & $\begin{array}{l}\text { RCT } \\
\text { Traditional } \\
\text { rehabilitation: } \\
\text { static and } \\
\text { dynamic } \\
\text { balance } \\
\text { exercises, gait } \\
\text { and } \\
\text { coordination } \\
\text { training }\end{array}$ & & $\begin{array}{l}\text { Dance: } 9 \text { (2f); age } \\
66.0 \text { years; H\&Y } 2.5 \text {; } \\
\text { duration } 6.0 \text { years. } \\
\text { Traditional } \\
\text { rehabilitation: } 7(3 f) ; \\
\text { age } 70.0 \text { years; H\&Y } \\
\text { 2.6; duration } 6.33 \\
\text { years. }\end{array}$ & $\begin{array}{l}\text { BBS; TUG; 6MWT; } \\
\text { DGI; 4SST. } \\
\text { Meds: on }\end{array}$ & 8 weeks & $\begin{array}{l}\text { Dance group improved on 6MWT } \\
(p=.003) \text {, TUG ( } p=.007) \text {; greater } \\
\text { improvement in TUG in dance vs. } \\
\text { traditional rehabilitation group } \\
\text { (interaction, } p=.009) \text {. } \\
\text { Improvements maintained at } 8 \text { week } \\
\text { follow-up. }\end{array}$ \\
\hline $\begin{array}{l}\text { Rabinovich } \\
\text { et al. (2017) }\end{array}$ & $\begin{array}{l}\text { Tango: } 2 \text { weeks, } 5 \\
\text { x } 90 \text { minutes. }\end{array}$ & $\begin{array}{l}\text { Uncontrolled } \\
\text { N/A }\end{array}$ & & $\begin{array}{l}8(N R) ; \text { age NR; H\&Y } \\
\text { 1-2; duration NR. }\end{array}$ & $\begin{array}{l}\text { MDS-UPDRS-III. } \\
\text { Meds: NR }\end{array}$ & $\mathrm{N} / \mathrm{A}$ & $\begin{array}{l}\text { Improvement in MDS-UPDRS-III } \\
(p<.05)\end{array}$ \\
\hline
\end{tabular}




\begin{tabular}{|c|c|c|c|c|c|c|c|}
\hline Article & $\begin{array}{l}\text { Dance } \\
\text { intervention: } \\
\text { duration, } \\
\text { frequency }\end{array}$ & $\begin{array}{l}\text { Study design; } \\
\text { control/ } \\
\text { comparison } \\
\text { group(s) }\end{array}$ & $\begin{array}{l}\text { References to } \\
\text { action } \\
\text { representation }\end{array}$ & $\begin{array}{l}\text { Participants per } \\
\text { group ( } \mathrm{n} \text { female); } \\
\text { age; Hoehn \& Yahr } \\
\text { stage (H\&Y); time } \\
\text { since diagnosis. }^{2}\end{array}$ & $\begin{array}{l}\text { Outcome measures; } \\
\text { medication status at } \\
\text { assessment (meds) }\end{array}$ & Follow-up & Results \\
\hline $\begin{array}{l}\text { Rawson et } \\
\text { al. (2019) }\end{array}$ & $\begin{array}{l}\text { Tango: } 12 \text { weeks, } \\
60 \text { minutes. }\end{array}$ & $\begin{array}{l}\text { Prospective } \\
\text { controlled trial } \\
\text { Treadmill } \\
\text { training } \\
\text { Stretching }\end{array}$ & & $\begin{array}{l}\text { Tango: } 39 \text { (14f), age } \\
66.7 \text { years; } H \& Y 1-4 ; \\
\text { duration } 6.1 \text { years. } \\
\text { Treadmill: } 31 \text { (14f), } \\
\text { age } 68.5 \text { years; } H \& Y \\
\text { 1-4; duration } 5.6 \\
\text { years. } \\
\text { Stretching: } 26 \text { (12f), } \\
\text { age } 66.2 \text { years; } H \& Y \\
\text { 2-4; duration } 4.4 \\
\text { years. }\end{array}$ & $\begin{array}{l}\text { MDS-UPDRS-III; Mini- } \\
\text { BESTest; 6MWT; gait } \\
\text { velocity and stride } \\
\text { length forwards and } \\
\text { backwards. } \\
\text { Meds: off }\end{array}$ & 12 weeks & $\begin{array}{l}\text { Dance group showed a trend* for } \\
\text { improvement on } 6 \text { MWT from } \\
\text { baseline to post-test }(p<.026) \text { but } \\
\text { declined from post-test to follow-up } \\
\text { ( } p<.01) \text {. Treadmill group showed } \\
\text { improved forward and backward gait } \\
\text { velocity }(p<.001 \text { ) at post-test and } \\
\text { follow-up. Stretching group } \\
\text { improved on backward velocity ( } p \\
<.01 \text { ) and UPDRS-III ( } p<.001 \text { ) from } \\
\text { baseline to post-test. } \\
\text { *Significance level adjusted for } \\
\text { multiple comparisons. }\end{array}$ \\
\hline $\begin{array}{l}\text { Rios } \\
\text { Romenets et } \\
\text { al. (2015) }\end{array}$ & $\begin{array}{l}\text { Tango: } 12 \text { weeks, } 2 \\
\text { x } 60 \text { minutes. }\end{array}$ & $\begin{array}{l}\text { Pilot RCT } \\
\text { Exercise: self- } \\
\text { directed daily } \\
\text { home practice } \\
\text { of exercises } \\
\text { provided in } \\
\text { pamphlet }\end{array}$ & & $\begin{array}{l}\text { Dance: } 18(6 f) ; \text { age } \\
63.2 \text { years; H\&Y } 1.7 ; \\
\text { duration } 5.5 \text { years. } \\
\text { Exercise: } 15 \text { (8f); age } \\
64.3 \text { years; H\&Y } 2.0 ; \\
\text { duration } 7.7 \text { years. }\end{array}$ & $\begin{array}{l}\text { MDS-UPDRS-III; Mini- } \\
\text { BESTest; TUG; TUG- } \\
\text { DT; walk with pivot } \\
\text { turns. } \\
\text { Meds: on }\end{array}$ & N/A & $\begin{array}{l}\text { Dance group improved vs. control } \\
\text { group on Mini-BESTest }(p=.03) \text {, TUG } \\
\text { time }(p=.04) \text {, TUG-DT }(p=.01) \text {, and } \\
\text { walking with pivot turns (trend; } \\
p=.07) \text {. }\end{array}$ \\
\hline $\begin{array}{l}\text { Shanahan et } \\
\text { al. (2015) }\end{array}$ & $\begin{array}{l}\text { Irish set dance: } 8 \\
\text { weeks, } 90 \text { minutes } \\
\text { plus home practice } \\
2 \times 20 \text { minutes. }\end{array}$ & $\begin{array}{l}\text { Uncontrolled } \\
\text { feasibility }\end{array}$ & Mental rehearsal & $\begin{array}{l}9(2 \mathrm{f}) ; 66.7 \text { age } \\
\text { years; H\&Y } 1.5 \\
\text { (Mdn); duration } 7.3 \\
\text { years. }\end{array}$ & $\begin{array}{l}\text { UPDRS-III; BBS; 6MWT } \\
\text { Meds: on }\end{array}$ & $\mathrm{N} / \mathrm{A}$ & $\begin{array}{l}\text { Trend towards improvement on } \\
\text { UPDRS-III ( } p=.05)\end{array}$ \\
\hline $\begin{array}{l}\text { Shanahan et } \\
\text { al. (2017) }\end{array}$ & $\begin{array}{l}\text { Irish set dance: } 10 \\
\text { weeks, } 90 \text { minutes } \\
\text { plus home practice } \\
3 \times 20 \text { minutes. }\end{array}$ & $\begin{array}{l}\text { Pilot RCT } \\
\text { Control: no } \\
\text { intervention }\end{array}$ & Mental rehearsal & $\begin{array}{l}\text { Dance: } 20 \text { (7f); age } \\
69.0 \text { years (Mdn); } \\
\text { H\&Y 1.25(Mdn); } \\
\text { duration } 5.5 \text { years. } \\
\text { Control: } 21(8 f) ; \text { age } \\
69.0 \text { years (Mdn); } \\
\text { H\&Y } 2.0 \text { (Mdn); } \\
\text { duration } 6.0 \text { years. }\end{array}$ & $\begin{array}{l}\text { UPDRS-III; Mini- } \\
\text { BESTest; } 6 \mathrm{MWT} \\
\text { Meds: on }\end{array}$ & N/A & $\begin{array}{l}\text { No significant changes in either } \\
\text { group. }\end{array}$ \\
\hline
\end{tabular}




\begin{tabular}{|c|c|c|c|c|c|c|c|}
\hline Article & $\begin{array}{l}\text { Dance } \\
\text { intervention: } \\
\text { duration, } \\
\text { frequency }\end{array}$ & $\begin{array}{l}\text { Study design; } \\
\text { control/ } \\
\text { comparison } \\
\text { group(s) }\end{array}$ & $\begin{array}{l}\text { References to } \\
\text { action } \\
\text { representation }\end{array}$ & $\begin{array}{l}\text { Participants per } \\
\text { group (n female); } \\
\text { age; Hoehn \& Yahr } \\
\text { stage (H\&Y); time } \\
\text { since diagnosis. }^{2}\end{array}$ & $\begin{array}{l}\text { Outcome measures; } \\
\text { medication status at } \\
\text { assessment (meds) }\end{array}$ & Follow-up & Results \\
\hline $\begin{array}{l}\text { Ventura et } \\
\text { al. (2016) }\end{array}$ & $\begin{array}{l}\text { Dance for PD: } 4.5 \\
\text { months, } 75 \\
\text { minutes. }\end{array}$ & $\begin{array}{l}\text { RCT } \\
\text { Control: no } \\
\text { intervention. }\end{array}$ & Mirroring & $\begin{array}{l}\text { Dance: } 8 \text { ( } 8 f) \text {; age } \\
71.8 \text { years; } H \& Y 1.7 ; \\
\text { duration } 6.1 \text { years. } \\
\text { Control: } 7 \text { ( } 5 f) \text {; age } \\
70.4 \text { years; } H \& Y 1.6 ; \\
\text { duration } 4.3 \text { years. }\end{array}$ & $\begin{array}{l}\text { TUG; Standing Balance } \\
\text { Test; Falls Efficacy } \\
\text { Scale-International; } \\
\text { gait speed (preferred). } \\
\text { Meds: on }\end{array}$ & $\mathrm{N} / \mathrm{A}$ & $\begin{array}{l}\text { Dance group showed large within- } \\
\text { group effect sizes }(\geq 0.8) \text { for gait } \\
\text { speed and Falls Efficacy. Control } \\
\text { group showed large positive effect } \\
\text { size for balance and large negative } \\
\text { effect size for gait speed. Large } \\
\text { between-group effect sizes showed } \\
\text { greater improvements for dance in } \\
\text { gait speed and falls efficacy. }\end{array}$ \\
\hline $\begin{array}{l}\text { Volpe et al. } \\
\text { (2013) }\end{array}$ & $\begin{array}{l}\text { Irish set dance: } 6 \\
\text { months, } 90 \\
\text { minutes. }\end{array}$ & $\begin{array}{l}\text { RCT } \\
\text { Exercise: } \\
\text { individual } \\
\text { physiotherapy } \\
\text { - strength, } \\
\text { mobility, } \\
\text { balance and } \\
\text { postural } \\
\text { control. }\end{array}$ & & $\begin{array}{l}\text { Dance: } 12 \text { ( } 5 f) \text {; age } \\
61.6 \text { years; } H \& Y 2.2 ; \\
\text { duration } 9.0 \text { years. } \\
\text { Exercise: } 12 \text { ( } 6 f) \text {; age } \\
65.0 \text { years; } H \& Y 2.2 ; \\
\text { duration } 8.9 \text { years. }\end{array}$ & $\begin{array}{l}\text { UPDRS-III; TUG; BBS; } \\
\text { FOG-Q. } \\
\text { Meds: NR }\end{array}$ & $\mathrm{N} / \mathrm{A}$ & $\begin{array}{l}\text { Both groups improved on UPDRS-III } \\
\text { and TUG ( } p<.001 \text { ), with interactions } \\
\text { showing greater improvements in } \\
\text { dance group (UPDRS-III, } p=.02 ; \text { TUG } \\
p=.007) \text {. Dance group also improved } \\
\text { on FOG-Q ( } p<.001 \text {; interaction } p \\
=.001 \text { ) and BBS (trend, } p=.05 \text { ). }\end{array}$ \\
\hline $\begin{array}{l}\text { Westbrook } \\
\text { \& McKibben } \\
\text { (1989) }\end{array}$ & $\begin{array}{l}\text { Dance/movement } \\
\text { therapy: } 6 \text { weeks, } \\
60 \text { minutes. }\end{array}$ & $\begin{array}{l}\text { Cross-over } \\
\text { Exercise: half } \\
\text { of participants } \\
\text { completed } 6 \\
\text { weeks of dance } \\
\text { intervention } \\
\text { first; half } \\
\text { completed } 6 \\
\text { weeks of } \\
\text { exercise first. }\end{array}$ & & $\begin{array}{l}37 \text { (n per group NR); } \\
\text { H\&Y 2-3; duration } \\
\text { NR. } \\
\text { Dance-first:14\% } \\
\text { female; age } 72.6 \\
\text { years. } \\
\text { Exercise-first: } 60 \% \\
\text { female; age } 69.9 \\
\text { years. }\end{array}$ & $\begin{array}{l}\text { Gait speed (fast). } \\
\text { Meds: NR }\end{array}$ & $\mathrm{N} / \mathrm{A}$ & $\begin{array}{l}\text { Both groups improved on gait speed } \\
\text { with dance vs. exercise }(p<.05) .\end{array}$ \\
\hline $\begin{array}{l}\text { Westheimer } \\
\text { et al. (2015) }\end{array}$ & $\begin{array}{l}\text { Dance for PD: } 8 \\
\text { weeks, } 2 \text { × } 75 \\
\text { minutes. }\end{array}$ & $\begin{array}{l}\text { Uncontrolled/ } \\
\text { mixed- } \\
\text { methods } \\
\text { N/A }\end{array}$ & Imagery, mirroring & $\begin{array}{l}12(6 f) ; \text { age } 66.2 \\
\text { years; H\&Y 2.33; } \\
\text { duration NR. }\end{array}$ & $\begin{array}{l}\text { Hoehn \& Yahr stage; } \\
\text { UPDRS-III; BBS. } \\
\text { Meds: on }\end{array}$ & $\mathrm{N} / \mathrm{A}$ & Improvement on UPDRS-III ( $p=.04)$. \\
\hline
\end{tabular}


${ }^{1}$ Duration and frequency of alternative interventions matching dance group unless specified; ${ }^{2}$ means or ranges reported unless specified.

$N R=$ not reported. $R C T=$ randomized controlled trial.

Test abbreviations: $4 S S T=$ four-square step test; $6 M W T=$ six-minute walking test; $A B C=$ Activities-Specific Balance Confidence scale; $B B S=B$ Berg Balance Scale; $F A B=F u l l e r t o n$ Advanced Balance scale; FOGQ = Freezing of Gait Questionnaire; Mini-BESTest $=$ Mini Balance Evaluation Systems Test; TUG = timed up and go; TUG-DT = timed up and go with dual task (cognitive unless stated); UPDRS = Unified Parkinson's Disease Rating Scale. 
Table S2. Non-motor outcomes of dance reported in people with PD

\begin{tabular}{|c|c|c|c|c|c|c|c|}
\hline Article & $\begin{array}{l}\text { Dance } \\
\text { intervention: } \\
\text { duration, } \\
\text { frequency }\end{array}$ & $\begin{array}{l}\text { Study design; } \\
\text { control/ } \\
\text { comparison } \\
\text { group(s). }{ }^{1}\end{array}$ & $\begin{array}{l}\text { References to } \\
\text { action } \\
\text { representation }\end{array}$ & $\begin{array}{l}\text { Participants per } \\
\text { group (n female); } \\
\text { age; Hoehn \& Yahr } \\
\text { stage (H\&Y); time } \\
\text { since diagnosis. }^{2}\end{array}$ & $\begin{array}{l}\text { Outcome measures; } \\
\text { medication status at } \\
\text { assessment (meds) }\end{array}$ & Follow-up & Results \\
\hline $\begin{array}{l}\text { Bearss et al. } \\
(2017)\end{array}$ & $\begin{array}{l}\text { Dance for PD: } 12 \\
\text { weeks (outcomes } \\
\text { tested at weeks } 2 \\
\text { and } 12 \text { ), } 75 \\
\text { minutes }\end{array}$ & $\begin{array}{l}\text { Uncontrolled } \\
\text { N/A }\end{array}$ & Imagery; mirroring & $\begin{array}{l}9(4 f) ; \text { age } 67.8 \\
\text { years; H\&Y } 0.8 \\
\text { duration } 5.6 \text { years. }\end{array}$ & $\begin{array}{l}\text { Oregon Health and } \\
\text { Sciences University } \\
\text { Quality of Life Scale; } \\
\text { well-being } \\
\text { questionnaire } \\
\text { administered } \\
\text { following classes. } \\
\text { Meds: NR }\end{array}$ & $\mathrm{N} / \mathrm{A}$ & $\begin{array}{l}\text { No overall change on QoL scale but } \\
\text { ratings on two individual questions } \\
\text { relating to relationships and learning } \\
\text { improved. }\end{array}$ \\
\hline $\begin{array}{l}\text { Blandy et al. } \\
\text { (2015) }\end{array}$ & $\begin{array}{l}\text { Tango: } 4 \text { weeks, } 60 \\
\text { minutes }\end{array}$ & $\begin{array}{l}\text { Uncontrolled } \\
\text { feasibility } \\
\text { N/A }\end{array}$ & N/A & $\begin{array}{l}6(3 f) ; \text { age } 64 \text { years; } \\
\text { H\&Y 2.0; duration } \\
8.6 \text { years. }\end{array}$ & $\begin{array}{l}\text { BDI; Euroqol-5D } \\
\text { Meds: on }\end{array}$ & N/A & Improvement on BDI scores. \\
\hline $\begin{array}{l}\text { Duncan \& } \\
\text { Earhart } \\
\text { (2012) }\end{array}$ & $\begin{array}{l}\text { Tango; } 12 \text { months } \\
\text { (outcomes tested } \\
\text { at } 3,6 \text { and } 12 \\
\text { months), } 2 \text { × } 60 \\
\text { minutes }\end{array}$ & $\begin{array}{l}\text { RCT } \\
\text { Control: no } \\
\text { intervention }\end{array}$ & & $\begin{array}{l}\text { Dance: } 26 \text { (11f); age } \\
69.3 \text { years; H\&Y } 2.6 \text {; } \\
\text { duration } 5.8 \text { years. } \\
\text { Control: } 26 \text { (11f); } \\
\text { age } 69 \text { years; H\&Y } \\
2.5 \text {; duration } 7 \\
\text { years. }\end{array}$ & $\begin{array}{l}\text { MDS-UPDRS I } \\
\text { Meds: off }\end{array}$ & N/A & No change in either group. \\
\hline $\begin{array}{l}\text { Duncan \& } \\
\text { Earhart } \\
(2014)\end{array}$ & $\begin{array}{l}\text { Tango: } 2 \text { years, } 2 x \\
60 \text { minutes }\end{array}$ & $\begin{array}{l}\text { RCT } \\
\text { Control: no } \\
\text { intervention. }\end{array}$ & & $\begin{array}{l}\text { Dance: } 5 \text { (1f); age } \\
69.6 \text { years; H\&Y } 2 \text { - } \\
\text { 3; duration } 6.6 \\
\text { years. } \\
\text { Control: } 5 \text { (1f); age } \\
66 \text { years; H\&Y 2- } 2.5 \text {; } \\
\text { duration } 11 \text { years. }\end{array}$ & $\begin{array}{l}\text { MDS-UPDRS-I } \\
\text { Meds: off }\end{array}$ & N/A & $\begin{array}{l}\text { Dance group improved on UPDRS-I } \\
\text { vs. control group at } 12 \text { and } 24 \\
\text { months (interaction, } p=.02 \text { ). }\end{array}$ \\
\hline
\end{tabular}




\begin{tabular}{|c|c|c|c|c|c|c|c|}
\hline Article & $\begin{array}{l}\text { Dance } \\
\text { intervention: } \\
\text { duration, } \\
\text { frequency }\end{array}$ & $\begin{array}{l}\text { Study design; } \\
\text { control/ } \\
\text { comparison } \\
\text { group(s). }{ }^{1}\end{array}$ & $\begin{array}{l}\text { References to } \\
\text { action } \\
\text { representation }\end{array}$ & $\begin{array}{l}\text { Participants per } \\
\text { group ( } \mathrm{n} \text { female); } \\
\text { age; Hoehn \& Yahr } \\
\text { stage (H\&Y); time } \\
\text { since diagnosis. }^{2}\end{array}$ & $\begin{array}{l}\text { Outcome measures; } \\
\text { medication status at } \\
\text { assessment (meds) }\end{array}$ & Follow-up & Results \\
\hline $\begin{array}{l}\text { Foster et al. } \\
(2013)\end{array}$ & $\begin{array}{l}\text { Tango: } 1 \text { year, } 2 \text { x } \\
60 \text { minutes }\end{array}$ & $\begin{array}{l}\text { RCT } \\
\text { Control: no } \\
\text { intervention. }\end{array}$ & & $\begin{array}{l}\text { Dance: } 26 \text { (11f); age } \\
69.3 \text { years; H\&Y 2-3; } \\
\text { duration } 5.8 \text { years. } \\
\text { Control: } 26 \text { (11f); } \\
\text { age } 69 \text { years; H\&Y } 2 \\
\text { - 4; duration } 7 \text { years. }\end{array}$ & $\begin{array}{l}\text { Activity Card Sort } \\
\text { Meds: Off }\end{array}$ & N/A & $\begin{array}{l}\text { Dance group showed increased } \\
\text { current participation at } 3,6 \text { and } 12 \\
\text { months ( } p<.008) ; \text { also increases in } \\
\text { retention of previous activities and } \\
\text { acquisition of new activities. Control } \\
\text { group showed no increase in } \\
\text { participation. }\end{array}$ \\
\hline $\begin{array}{l}\text { Hackney et } \\
\text { al. (2007b) }\end{array}$ & $\begin{array}{l}\text { Tango: } 13 \text { weeks } \\
\text { (10 weeks of } \\
\text { classes), } 2 \text { × } 60 \\
\text { minutes }\end{array}$ & $\begin{array}{l}\text { RCT } \\
\text { Exercise: } \\
\text { structured } \\
\text { traditional } \\
\text { strength/ } \\
\text { flexibility } \\
\text { training. }\end{array}$ & Imagery & $\begin{array}{l}\text { Dance: } 9 \text { (NR). } \\
\text { Control: } 10 \text { (NR). } \\
\text { Matched numbers of } \\
\text { healthy controls in } \\
\text { each group; all 55+ } \\
\text { years. Disease stage } \\
\text { and duration NR. }\end{array}$ & $\begin{array}{l}\text { 17-item Philadelphia } \\
\text { Geriatric Center } \\
\text { Morale Scale } \\
\text { Meds: NR }\end{array}$ & N/A & No change in either group. \\
\hline $\begin{array}{l}\text { Hackney \& } \\
\text { Earhart } \\
\text { (2009c) }\end{array}$ & $\begin{array}{l}\text { Tango, } \\
\text { Waltz/Foxtrot: } 13 \\
\text { weeks (10 weeks } \\
\text { of classes), } 2 \text { x } 60 \\
\text { minutes }\end{array}$ & $\begin{array}{l}\text { RCT } \\
\text { Tai Chi. } \\
\text { Control: no } \\
\text { intervention. }\end{array}$ & & $\begin{array}{l}\text { Tango: } 14 \text { (3f); age } \\
68.2 \text { years; H\&Y } 2.1 \text {; } \\
\text { duration } 6.9 \text { years. } \\
\text { Waltz/Foxtrot: } 17 \\
\text { (6f); age } 66.8 \text { years; } \\
\text { H\&Y 2.0; duration } \\
\text { 9.2 years. } \\
\text { Control: } 17 \text { (5f); age } \\
66.5 \text { years; H\&Y } 2.2 \text {; } \\
\text { duration } 5.9 \text { years. } \\
\text { Tai Chi: } 13 \text { ( } 2 \text { f); age } \\
64.9 \text { years; H\&Y 2.0; } \\
\text { duration } 8.7 \text { years. }\end{array}$ & $\begin{array}{l}\text { PDQ-39 } \\
\text { Meds: on }\end{array}$ & N/A & $\begin{array}{l}\text { Tango group improved on PDQ-39 } \\
\text { domains of Mobility ( } p=0.03 \text { ), Social } \\
\text { Support ( } p=0.05 \text { ) and PDQ-39 } \\
\text { Summary Index ( } p<0.01 \text { ). No } \\
\text { changes in Waltz/Foxtrot, Tai Chi or } \\
\text { control group. }\end{array}$ \\
\hline
\end{tabular}




\begin{tabular}{|c|c|c|c|c|c|c|c|}
\hline Article & $\begin{array}{l}\text { Dance } \\
\text { intervention: } \\
\text { duration, } \\
\text { frequency }\end{array}$ & $\begin{array}{l}\text { Study design; } \\
\text { control/ } \\
\text { comparison } \\
\text { group(s). }{ }^{1}\end{array}$ & $\begin{array}{l}\text { References to } \\
\text { action } \\
\text { representation }\end{array}$ & $\begin{array}{l}\text { Participants per } \\
\text { group ( } \mathrm{n} \text { female); } \\
\text { age; Hoehn \& Yahr } \\
\text { stage (H\&Y); time } \\
\text { since diagnosis. }^{2}\end{array}$ & $\begin{array}{l}\text { Outcome measures; } \\
\text { medication status at } \\
\text { assessment (meds) }\end{array}$ & Follow-up & Results \\
\hline $\begin{array}{l}\text { Hashimoto } \\
\text { et al. (2015) }\end{array}$ & $\begin{array}{l}\text { Modern dance: } 12 \\
\text { weeks, } 60 \\
\text { minutes. }\end{array}$ & $\begin{array}{l}\text { Quasi-RCT } \\
\text { Exercise: } \\
\text { physical } \\
\text { therapy and } \\
\text { PD-specific } \\
\text { exercises. } \\
\text { Control: no } \\
\text { intervention. }\end{array}$ & Visualisation & $\begin{array}{l}\text { Dance: } 15 \text { (12f); age } \\
67.9 \text { years; H\&Y } 2.7 ; \\
\text { duration } 6.3 \text { years. } \\
\text { Exercise: } 17 \text { (15f); } \\
\text { age } 62.7 \text { years; H\&Y } \\
2.7 ; \text { duration } 7.8 \\
\text { years. } \\
\text { Control group: } 14 \\
\text { (7f); age } 69.7 \text { years; } \\
\text { H\&Y 3.0; duration } \\
6.9 \text { years. }\end{array}$ & $\begin{array}{l}\text { Frontal Assessment } \\
\text { Battery at bedside; } \\
\text { Mental Rotation Task; } \\
\text { SDS; AS. } \\
\text { Meds: on }\end{array}$ & N/A & $\begin{array}{l}\text { Dance and Exercise groups improved } \\
\text { on Frontal Assessment Battery } \\
\text { (dance } p=.001 \text {; exercise } p=.01 \text { ) and } \\
\text { Mental Rotation Task (dance } p<.001 ; \\
\text { exercise } p=.002 \text { ). Dance group also } \\
\text { improved on AS ( } p<.001 \text { ) and SDS } \\
(p=.006) \text {. }\end{array}$ \\
\hline $\begin{array}{l}\text { Heiberger et } \\
\text { al. (2011) }\end{array}$ & $\begin{array}{l}\text { Mixed style: } 8 \\
\text { months, } 75 \\
\text { minutes } \\
\text { (outcomes tested } \\
\text { only after } 8 \\
\text { months of } \\
\text { participation). }\end{array}$ & $\begin{array}{l}\text { Uncontrolled } \\
\text { N/A }\end{array}$ & Motor imagery & $\begin{array}{l}11(6 f) ; \text { age } 71.3 \\
\text { years; H\&Y 3.3; } \\
\text { duration NR. }\end{array}$ & $\begin{array}{l}\text { Modified Oregon } \\
\text { Health and Sciences } \\
\text { University Quality of } \\
\text { Life Scale; well-being } \\
\text { questionnaire } \\
\text { Meds: off }\end{array}$ & N/A & $\begin{array}{l}\text { Self-reported improvements in } \\
\text { mood, mobility and quality of life. }\end{array}$ \\
\hline $\begin{array}{l}\text { Lewis et al. } \\
(2016)\end{array}$ & $\begin{array}{l}\text { Mixed styles } \\
\text { changing every } \\
\text { two weeks: } 12 \\
\text { weeks (10 weeks } \\
\text { of classes), } 50 \\
\text { minutes }\end{array}$ & $\begin{array}{l}\text { Uncontrolled } \\
\text { N/A }\end{array}$ & & $\begin{array}{l}18(N R) ; \text { age } 65.9 \\
\text { years; H\&Y 1- 3; } \\
\text { duration NR. Also } 10 \\
\text { healthy controls; age } \\
64.5 \text { years. }\end{array}$ & $\begin{array}{l}\text { Long- and short-cycle } \\
\text { mood assessment: } \\
\text { Profile of Mood States } \\
\text { before and after } 12 \\
\text { weeks; Brunel } \\
\text { University Mood Scale } \\
\text { before and after 9th } \\
\text { class. } \\
\text { Meds: on }\end{array}$ & N/A & $\begin{array}{l}\text { Long-cycle: PD and control } \\
\text { participants showed improvement in } \\
\text { overall mood and decreased anger. } \\
\text { Short-cycle: no effects found. }\end{array}$ \\
\hline
\end{tabular}




\begin{tabular}{|c|c|c|c|c|c|c|c|}
\hline Article & $\begin{array}{l}\text { Dance } \\
\text { intervention: } \\
\text { duration, } \\
\text { frequency }\end{array}$ & $\begin{array}{l}\text { Study design; } \\
\text { control/ } \\
\text { comparison } \\
\text { group(s). }{ }^{1}\end{array}$ & $\begin{array}{l}\text { References to } \\
\text { action } \\
\text { representation }\end{array}$ & $\begin{array}{l}\text { Participants per } \\
\text { group ( } \mathrm{n} \text { female); } \\
\text { age; Hoehn \& Yahr } \\
\text { stage (H\&Y); time } \\
\text { since diagnosis. }^{2}\end{array}$ & $\begin{array}{l}\text { Outcome measures; } \\
\text { medication status at } \\
\text { assessment (meds) }\end{array}$ & Follow-up & Results \\
\hline $\begin{array}{l}\text { McKee \& } \\
\text { Hackney } \\
(2013)\end{array}$ & $\begin{array}{l}\text { Tango: } 12 \text { weeks } \\
\text { (10 weeks of } \\
\text { classes), } 90 \\
\text { minutes }\end{array}$ & $\begin{array}{l}\text { RCT } \\
\text { Educational } \\
\text { seminars: } \\
\text { lectures, } \\
\text { discussion and } \\
\text { structured } \\
\text { group learning } \\
\text { activities. }\end{array}$ & & $\begin{array}{l}\text { Dance: } 24 \text { (12f); age } \\
68.4 \text { years; H\&Y } 2.3 \\
\text { (Mdn); duration } 7.0 \\
\text { years. } \\
\text { Education: } 9 \text { (1f); } \\
\text { age } 74.4 \text { years; H\&Y } \\
2.0 \text { (Mdn); duration } \\
7.2 \text { years. }\end{array}$ & $\begin{array}{l}\text { PDQ-39; MoCA; } \\
\text { Reverse Corsi Blocks; } \\
\text { Brooks Spatial Task; } \\
\text { Short Form health } \\
\text { survey-12 (SF-12). } \\
\text { Meds: on }\end{array}$ & $\begin{array}{l}10-12 \\
\text { weeks }\end{array}$ & $\begin{array}{l}\text { Both groups improved on MoCA ( } p \\
=.01 \text { ). Dance group also improved on } \\
\text { Brooks Spatial Task (interaction } p \\
=.02 \text { ), which was maintained at } \\
\text { follow-up. }\end{array}$ \\
\hline $\begin{array}{l}\text { McNeely et } \\
\text { al. (2015) }\end{array}$ & $\begin{array}{l}\text { Dance for PD, } \\
\text { Tango: } 12 \text { weeks, } 2 \\
\text { x } 60 \text { minutes }\end{array}$ & $\begin{array}{l}\text { Between- } \\
\text { groups }\end{array}$ & Imagery; mirroring & $\begin{array}{l}\text { Dance for PD: } 8(4 f) \text {; } \\
\text { age } 68.3 \text { years; } \mathrm{H} \& Y \\
2.3 \text {; duration } 10.1 \\
\text { years. } \\
\text { Tango: } 8 \text { (4f); age } \\
67.7 \text { years; H\&Y } 2.1 \text {; } \\
\text { duration } 5.4 \text { years. }\end{array}$ & $\begin{array}{l}\text { PDQ-39 } \\
\text { Meds: off }\end{array}$ & $\mathrm{N} / \mathrm{A}$ & No change in either group. \\
\hline $\begin{array}{l}\text { De Natale et } \\
\text { al. (2017) }\end{array}$ & $\begin{array}{l}\text { Tango: } 10 \text { weeks, } 2 \\
\text { x } 60 \text { minutes }\end{array}$ & $\begin{array}{l}\text { RCT } \\
\text { Traditional } \\
\text { rehabilitation: } \\
\text { static and } \\
\text { dynamic } \\
\text { balance } \\
\text { exercises, gait } \\
\text { and } \\
\text { coordination } \\
\text { training }\end{array}$ & & $\begin{array}{l}\text { Dance: } 9 \text { ( } 2 \mathrm{f}) \text {; age } \\
66.0 \text { years; } \mathrm{H} \& \mathrm{Y} 2.5 \text {; } \\
\text { duration } 6.0 \text { years. } \\
\text { Traditional } \\
\text { rehabilitation: } 7(3 f) \text {; } \\
\text { age } 70.0 \text { years; } H \& Y \\
\text { 2.6; duration } 6.33 \\
\text { years. }\end{array}$ & $\begin{array}{l}\text { Frontal Assessment } \\
\text { Battery, TMT A and B; } \\
\text { Stroop Test. } \\
\text { Meds: on }\end{array}$ & 8 weeks & $\begin{array}{l}\text { Interactions showed greater } \\
\text { improvements for dance vs. } \\
\text { rehabilitation on TMT-B }(p=.04) \text {. } \\
\text { Dance group also improved on TMT- } \\
\text { A ( } p=.01) \text {. Effects maintained at } 8 \\
\text { week follow-up. }\end{array}$ \\
\hline
\end{tabular}




\begin{tabular}{|c|c|c|c|c|c|c|c|}
\hline Article & $\begin{array}{l}\text { Dance } \\
\text { intervention: } \\
\text { duration, } \\
\text { frequency }\end{array}$ & $\begin{array}{l}\text { Study design; } \\
\text { control/ } \\
\text { comparison } \\
\text { group(s). }{ }^{1}\end{array}$ & $\begin{array}{l}\text { References to } \\
\text { action } \\
\text { representation }\end{array}$ & $\begin{array}{l}\text { Participants per } \\
\text { group (n female); } \\
\text { age; Hoehn \& Yahr } \\
\text { stage (H\&Y); time } \\
\text { since diagnosis. }{ }^{2}\end{array}$ & $\begin{array}{l}\text { Outcome measures; } \\
\text { medication status at } \\
\text { assessment (meds) }\end{array}$ & Follow-up & Results \\
\hline $\begin{array}{l}\text { Rawson et } \\
\text { al. (2019) }\end{array}$ & $\begin{array}{l}\text { Tango: } 12 \text { weeks, } \\
60 \text { minutes. }\end{array}$ & $\begin{array}{l}\text { Prospective } \\
\text { controlled trial } \\
\text { Treadmill } \\
\text { training } \\
\text { Stretching }\end{array}$ & & $\begin{array}{l}\text { Tango: } 39 \text { (14f), age } \\
66.7 \text { years; } \mathrm{H} \& Y \text { 1-4; } \\
\text { duration } 6.1 \text { years. } \\
\text { Treadmill: } 31 \text { (14f), } \\
\text { age } 68.5 \text { years; } \mathrm{H} \& Y \\
\text { 1-4; duration } 5.6 \\
\text { years. } \\
\text { Stretching: } 26 \text { (12f), } \\
\text { age } 66.2 \text { years; } \mathrm{H} \& Y \\
\text { 2-4; duration } 4.4 \\
\text { years. }\end{array}$ & $\begin{array}{l}\text { PDQ-39 } \\
\text { Meds: off }\end{array}$ & 12 weeks & $\begin{array}{l}\text { Only stretching group improved from } \\
\text { post-test to follow-up }(p<.001)\end{array}$ \\
\hline $\begin{array}{l}\text { Rios } \\
\text { Romenets et } \\
\text { al. (2015) }\end{array}$ & $\begin{array}{l}\text { Tango: } 12 \text { weeks, } 2 \\
\text { x } 60 \text { minutes }\end{array}$ & $\begin{array}{l}\text { Pilot RCT } \\
\text { Exercise: self- } \\
\text { directed daily } \\
\text { home practice } \\
\text { of exercises } \\
\text { provided in } \\
\text { pamphlet }\end{array}$ & & $\begin{array}{l}\text { Dance: } 18 \text { ( } 6 f) \text {; age } \\
63.2 \text { years; H\&Y } 1.7 \text {; } \\
\text { duration } 5.5 \text { years. } \\
\text { Control: } 15 \text { ( } 8 f) \text {; age } \\
64.3 \text { years; H\&Y } 2.0 \text {; } \\
\text { duration } 7.7 \text { years. }\end{array}$ & $\begin{array}{l}\text { MoCA; BDI, AS, Krupp } \\
\text { Fatigue Severity Scale. } \\
\text { Meds: on }\end{array}$ & N/A & $\begin{array}{l}\text { Trends for improvement on MoCA ( } p \\
=.08 \text { ) and Fatigue Severity Scale ( } p \\
=.06) .\end{array}$ \\
\hline $\begin{array}{l}\text { Shanahan et } \\
\text { al. (2015) }\end{array}$ & $\begin{array}{l}\text { Irish set dance: } 8 \\
\text { weeks, } 90 \text { minutes } \\
\text { plus home practice } \\
2 \times 20 \text { minutes. }\end{array}$ & $\begin{array}{l}\text { Uncontrolled } \\
\text { feasibility }\end{array}$ & Mental rehearsal & $\begin{array}{l}9(2 \mathrm{f}) ; 66.7 \text { age } \\
\text { years; H\&Y } 1.5 \\
\text { (Mdn); duration } 7.3 \\
\text { years. }\end{array}$ & $\begin{array}{l}\text { PDQ-39 } \\
\text { Meds: on }\end{array}$ & & $\begin{array}{l}\text { Significant improvement on PDQ-39 } \\
(p=.01)\end{array}$ \\
\hline $\begin{array}{l}\text { Shanahan et } \\
\text { al. (2017) }\end{array}$ & $\begin{array}{l}\text { Irish set dance: } 10 \\
\text { weeks, } 90 \text { minutes } \\
\text { plus home practice } \\
3 \times 20 \text { minutes. }\end{array}$ & $\begin{array}{l}\text { Pilot RCT } \\
\text { Control: no } \\
\text { intervention }\end{array}$ & Mental rehearsal & $\begin{array}{l}\text { Dance: } 20(7 f) ; \text { age } \\
69.0 \text { years (Mdn); } \\
\text { H\&Y } 1.25(\mathrm{Mdn}) ; \\
\text { duration } 5.5 \text { years. } \\
\text { Control: } 21(8 \mathrm{f}) \text {; age } \\
69.0 \text { years (Mdn); } \\
\text { H\&Y } 2.0 \text { (Mdn); } \\
\text { duration } 6.0 \text { years. }\end{array}$ & $\begin{array}{l}\text { PDQ-39 } \\
\text { Meds: on }\end{array}$ & & $\begin{array}{l}\text { No significant changes in either } \\
\text { group. }\end{array}$ \\
\hline
\end{tabular}




\begin{tabular}{|c|c|c|c|c|c|c|c|}
\hline Article & $\begin{array}{l}\text { Dance } \\
\text { intervention: } \\
\text { duration, } \\
\text { frequency }\end{array}$ & $\begin{array}{l}\text { Study design; } \\
\text { control/ } \\
\text { comparison } \\
\text { group(s). }{ }^{1}\end{array}$ & $\begin{array}{l}\text { References to } \\
\text { action } \\
\text { representation }\end{array}$ & $\begin{array}{l}\text { Participants per } \\
\text { group ( } \mathrm{n} \text { female); } \\
\text { age; Hoehn \& Yahr } \\
\text { stage (H\&Y); time } \\
\text { since diagnosis. }\end{array}$ & $\begin{array}{l}\text { Outcome measures; } \\
\text { medication status at } \\
\text { assessment (meds) }\end{array}$ & Follow-up & Results \\
\hline $\begin{array}{l}\text { Ventura et } \\
\text { al. (2016) }\end{array}$ & $\begin{array}{l}\text { Dance for PD: } 4.5 \\
\text { months, } 75 \\
\text { minutes }\end{array}$ & $\begin{array}{l}\text { RCT } \\
\text { Control: no } \\
\text { intervention. }\end{array}$ & Mirroring & $\begin{array}{l}\text { Dance: } 8 \text { ( } 8 f) \text {; age } \\
71.8 \text { years; } H \& Y 1.7 \text {; } \\
\text { duration } 6.1 \text { years. } \\
\text { Control: } 7 \text { ( } 5 f) \text {; age } \\
70.4 \text { years; H\&Y } 1.6 \text {; } \\
\text { duration } 4.3 \text { years. }\end{array}$ & $\begin{array}{l}\text { TEA visual elevator } \\
\text { test; action fluency; } \\
\text { category fluency; digit } \\
\text { span forward and } \\
\text { backward; GDS; PDQ- } \\
39 . \\
\text { Meds: on }\end{array}$ & N/A & $\begin{array}{l}\text { Dance group: large within-group } \\
\text { effect sizes ( } \geq 0.8 \text { ) for TEA, digit span } \\
\text { forward and GDS; large effect size in } \\
\text { favour of dance group for TEA. }\end{array}$ \\
\hline $\begin{array}{l}\text { Volpe et al. } \\
\text { (2013) }\end{array}$ & $\begin{array}{l}\text { Irish set dance: } 6 \\
\text { months, } 90 \\
\text { minutes. }\end{array}$ & $\begin{array}{l}\text { RCT } \\
\text { Exercise: } \\
\text { individual } \\
\text { physiotherapy } \\
\text { sessions - } \\
\text { strength, } \\
\text { mobility, } \\
\text { balance and } \\
\text { postural } \\
\text { control. }\end{array}$ & & $\begin{array}{l}\text { Dance: } 12 \text { ( } 5 f) \text {; age } \\
61.6 \text { years; H\&Y } 2.2 \text {; } \\
\text { duration } 9.0 \text { years. } \\
\text { Exercise: } 12 \text { ( } 6 f) \text {; age } \\
65.0 \text { years; H\&Y } 2.2 \text {; } \\
\text { duration } 8.9 \text { years. }\end{array}$ & $\begin{array}{l}\text { PDQ-39 } \\
\text { Meds: NR }\end{array}$ & $N / A$ & No change in either group. \\
\hline $\begin{array}{l}\text { Westbrook } \\
\text { \& McKibben } \\
\text { (1989) }\end{array}$ & $\begin{array}{l}\text { Dance/ movement } \\
\text { therapy: } 6 \text { weeks, } \\
60 \text { minutes. }\end{array}$ & $\begin{array}{l}\text { Cross-over } \\
\text { Exercise: } \\
50 \% \\
\text { participants } \\
\text { completed } \\
\text { dance } \\
\text { intervention } \\
\text { first; } 50 \% \\
\text { completed } \\
\text { exercise first. }\end{array}$ & & $\begin{array}{l}37 \text { (n per group NR); } \\
\text { H\&Y } 2 \text { - 3; duration } \\
\text { NR. } \\
\text { Dance-first group } \\
\text { 14\% female; age } \\
72.6 \text { years. } \\
\text { Exercise-first group } \\
60 \% \text { female; age } \\
69.9 \text { years. }\end{array}$ & $\begin{array}{l}\text { BDI } \\
\text { Meds: NR }\end{array}$ & $\mathrm{N} / \mathrm{A}$ & No change in either group. \\
\hline
\end{tabular}




\begin{tabular}{|c|c|c|c|c|c|c|c|}
\hline Article & $\begin{array}{l}\text { Dance } \\
\text { intervention: } \\
\text { duration, } \\
\text { frequency }\end{array}$ & $\begin{array}{l}\text { Study design; } \\
\text { control/ } \\
\text { comparison } \\
\text { group(s). }{ }^{1}\end{array}$ & $\begin{array}{l}\text { References to } \\
\text { action } \\
\text { representation }\end{array}$ & $\begin{array}{l}\text { Participants per } \\
\text { group ( } \mathrm{n} \text { female); } \\
\text { age; Hoehn \& Yahr } \\
\text { stage (H\&Y); time } \\
\text { since diagnosis. }^{2}\end{array}$ & $\begin{array}{l}\text { Outcome measures; } \\
\text { medication status at } \\
\text { assessment (meds) }\end{array}$ & Follow-up & Results \\
\hline $\begin{array}{l}\text { Westheimer } \\
\text { et al. (2008) }\end{array}$ & $\begin{array}{l}\text { Dance for PD: } \\
\text { ongoing classes, } 75 \\
\text { minutes. } \\
\text { Assessment } \\
\text { conducted after } \\
\text { classes running for } \\
17 \text { months. }\end{array}$ & $\begin{array}{l}\text { Uncontrolled } \\
\text { N/A }\end{array}$ & Imagery; mirroring & $\begin{array}{l}15(8 \mathrm{f}) \text { respondents } \\
\text { from ongoing class; } \\
\text { age } 50-87 \text { years; } \\
\text { H\&Y } 1-4 \text {; duration } 1- \\
10 \text { years. }\end{array}$ & $\begin{array}{l}\text { Modified Oregon } \\
\text { Health and Sciences } \\
\text { University Quality of } \\
\text { Life Scale; qualitative } \\
\text { investigation via } \\
\text { questions emailed to } 5 \\
\text { participants. } \\
\text { Meds: on }\end{array}$ & N/A & $\begin{array}{l}\text { Self-reported improvements in } \\
\text { quality of life including physical } \\
\text { health, socialisation, creative } \\
\text { expression, and mobility. }\end{array}$ \\
\hline $\begin{array}{l}\text { Westheimer } \\
\text { et al. (2015) }\end{array}$ & $\begin{array}{l}\text { Dance for PD: } 8 \\
\text { weeks, } 2 \text { × } 75 \\
\text { minutes. }\end{array}$ & $\begin{array}{l}\text { Uncontrolled/ } \\
\text { mixed- } \\
\text { methods } \\
\text { N/A }\end{array}$ & Imagery; imitation & $\begin{array}{l}12(6 f) ; \text { age } 66.2 \\
\text { years; H\&Y 2.33; } \\
\text { duration NR. }\end{array}$ & $\begin{array}{l}\text { PDQ-39 Summary } \\
\text { Index; BDI. } \\
\text { Meds: on }\end{array}$ & $\mathrm{N} / \mathrm{A}$ & \\
\hline
\end{tabular}

${ }^{1}$ Duration and frequency of alternative interventions matching dance group unless specified; ${ }^{2}$ means or ranges reported unless specified.

$N R=$ not reported. $R C T=$ randomized controlled trial.

Test abbreviations: $A S=$ Apathy Scale $B D I=$ Beck Depression Inventory; $G D I=$ Geriatric Depression Inventory; MocA $=$ Montreal Cognitive Assessment; $P D Q-39=$ Parkinson's Disease Questionnaire; SDS = Self-report Depression Scale; TEA = Test of Everyday Attention; TMT = Trail Making Test; UPDRS = Unified Parkinson's Disease Rating Scale. 